\title{
Physiological, nutritional, and molecular responses of Brazilian sugarcane cultivars under stress by aluminum
}

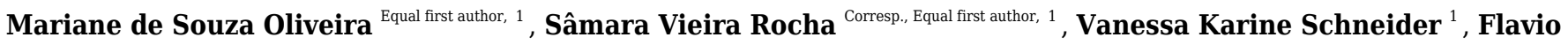 \\ Henrique-Silva ${ }^{1}$, Marcio Roberto Soares ${ }^{2}$, Andrea Soares-Costa ${ }^{\text {Corresp. } 1}$ \\ ${ }^{1}$ Department of Genetics and Evolution, Federal University of São Carlos, São Carlos, SP, Brazil \\ 2 Department of Natural Resources and Environmental Protection/Agrarian Sciences Center, Federal University of São Carlos, Araras, SP, Brazil \\ Corresponding Authors: Sâmara Vieira Rocha, Andrea Soares-Costa \\ Email address: samara.vieira@hotmail.com, andreasc@ufscar.br
}

Background. Sugarcane is a crop of global importance and has been expanding to areas with soils containing high levels of exchangeable aluminum (Al), which is a limiting factor for crop development in acidic soils. The study of the sugarcane physiological and nutritional behavior together with patterns of gene expression in response to Al stress may provide a basis for effective strategies to increase crop productivity in acidic soils.

Methods. Sugarcane cultivars were evaluated for physiological parameters (photosynthesis, stomatal conductance, and transpiration), nutrient ( $\mathrm{N}, \mathrm{P}, \mathrm{K}, \mathrm{Ca}, \mathrm{Mg}$, and S) and Al contents in leaves and roots and gene expression, of the genes $M D H, S D H$ by qPCR, both related to the production of organic acids, and $S O D$, related to oxidative stress. Results. Brazilian sugarcane RB867515, RB928064, and RB935744 cultivars exhibited very different responses to induced stress by Al. Exposure to Al caused up-regulation (SOD and $M D H$ ) or down-regulation (SDH, $M D H$, and $S O D)$, depending on the cultivar, Al level, and plant tissue. The RB867515 was the most Al-tolerant cultivar, showing no decline of nutrient content in plant tissue, photosynthesis, transpiration, and stomatal conductance after exposure to Al; it exhibited the highest Al content in the roots, and showed important $M D H$ and SOD gene expression in the roots. RB928064 only showed low expression of SOD in roots and leaves, while RB935744 showed important expression of the SOD gene only in the leaves. Sugarcane cultivars were classified in the following descending Al-tolerance order: RB867515>RB928064=RB935744. These results may contribute to the obtention of Al-tolerant cultivars that can play their genetic potential in soils of low fertility and with low demand for agricultural inputs; the selection of potential plants for breeding programs; the elucidation of Al detoxification mechanisms employed by sugarcane cultivars. 
1 Physiological, nutritional, and molecular responses of Brazilian sugarcane cultivars under

2 stress by aluminum

3

4 Mariane de Souza Oliveira ${ }^{1 \star}$, Sâmara Vieira Rocha ${ }^{1}$, Vanessa Karine Schneider ${ }^{1}$, Flavio

5 Henrique-Silva ${ }^{1}$, Marcio Roberto Soares ${ }^{2}$ and Andrea Soares-Costa ${ }^{1}$

${ }^{1}$ Department of Genetics and Evolution, Federal University of São Carlos, São Carlos, SP,

8 Brazil

$9{ }^{2}$ Department of Natural Resources and Environmental Protection, Agrarian Sciences

Corresponding Author:

Sâmara Rocha ${ }^{1}$

Highway Washington Luiz, Km 235, São Carlos, SP, 13.565-905, Brazil

Email address: samararocha@estudante.ufscar.br

Andrea Soares-Costa ${ }^{1}$

Highway Washington Luiz, Km 235, São Carlos, SP, 13.565-905, Brazil

Email address: andreasc@ufscar.br

- These authors contributed equally to the work.

\section{Abstract}

Background. Sugarcane is a globally important crop. Its cultivation has expanded to areas with soils containing high levels of exchangeable aluminum (Al), a limiting factor for crop development in acidic soils. The study of the sugarcane's physiological and nutritional behavior together with its gene expression patterns in response to Al stress may provide a basis for effective strategies to increase crop productivity in acidic soils.

Methods. Sugarcane cultivars were evaluated for physiological parameters (photosynthesis, stomatal conductance, and transpiration), nutrient ( $, \mathrm{P}, \mathrm{K}, \mathrm{Ca}, \mathrm{Mg}$, and $\mathrm{S}$ ) and $\mathrm{Al}$ content of leaves and roots, and expression of the genes $M D H, S D H$ by qPCR. Both genes are related to production of organic acids while $S O D$ is related to oxidative stress.

Results. Brazilian sugarcane RB867515, RB928064, and RB935744 cultivars exhibited very different responses to induced stress by Al. Exposure to Al caused up-regulation (SOD and $M D H)$ or down-regulation $(S D H, M D H$, and $S O D)$, depending on the cultivar, Al level, and plant tissue. The RB867515 was the most Al-tolerant cultivar, showing no decline of nutrient content in plant tissue, photosynthesis, transpiration, and stomatal conductance after exposure to $\mathrm{Al}$; it exhibited the highest $\mathrm{Al}$ content in the roots, and showed important $M D H$ and SOD gene 
expression in the roots. RB928064 only showed low expression of $S O D$ in roots and leaves, while RB935744 showed important expression of the SOD gene only in the leaves. Sugarcane cultivars were classified in the following descending Al-tolerance order:

RB867515>RB928064=RB935744. These results may contribute to the obtainment of Altolerant cultivars that can play their genetic potential in soils of low fertility and with low demand for agricultural inputs; the selection of potential plants for breeding programs; and the elucidation of Al detoxification mechanisms employed by sugarcane cultivars.

\section{Introduction}

Sugarcane crop has global economic importance with a harvested area of 27.6 million hectares, and a 2-billion-ton production. Brazil is the largest producer followed by India, China, and Thailand (FAO, 2018). It is estimated that 630.7 million tons will be harvested in the 2020/21 Brazilian harvest seasons (Conab, 2020).

Sugarcane plantations are often criticized for occupying large extensions of fertile arable land that could be used for food production. As a C4 plant, sugarcane has high photosynthetic efficiency (Sales et al., 2018). It accumulates large biomass under tropical climate conditions, with a high potential for cultivation on non-favorable agricultural land. Establishing sugarcane plantations on marginal and degraded lands is an important strategy to avoid land-use change and competition for areas used for food production or environmental preservation (Furtado et al., 2014; Bordonal et al., 2018).

Sugarcane has been mainly planted in the Southeast region of Brazil, close to most sugarcane mills. Since 2005, sugarcane cropping started expanding fast towards Central Brazil, a region that is dominated by the Cerrado biome (Filoso et al., 2015; Arruda, Giller \& Slingerland, 2017). Cerrado is a savanna vegetation type that is generally flat with many microelevations (Arruda, Giller \& Slingerland, 2017). It is ideal for mechanization and suitable for large-scale cropping and cattle-raising due to its soil and climate. Soil fertility is among the main biotic and abiotic factors influencing the productivity and technological quality of sugarcane (Viana et al., 2020). Soils from Central Brazil present high acidity, high levels of exchangeable aluminum $\left(\mathrm{Al}^{3+}\right)$, and a general deficiency of nutrients (mainly phosphorus, calcium, and magnesium) (Yamada, 2005). Acid soils comprise large agricultural areas in tropical and subtropical regions, which comprises approximately 50\% of the arable land (Sade et al., 2016; Singh et al., 2017).

Soil Al solubility increases at low $\mathrm{pH}$ levels (mainly at $\mathrm{pH}_{\mathrm{H} 2 \mathrm{O}} \leq 5.0$ ), and its toxicity is a limiting factor for crop development in acidic soils (Ryan, 2018). The most sensitive plant region to $\mathrm{Al}$ is the root apex (Gupta, Gaurav \& Kumar et al., 2013; Rao et al., 2016; Ryan, 2018; Yadav et al., 2020). The cation $\mathrm{Al}^{3+}$ binds to the cell wall, particularly in the pectin matrix, negatively charged with carboxylic groups; it also binds to the apoplastic side of the plasma membrane, impairing its function (Horst, Wang \& Eticha et al., 2010). The cation interferes with cell division and root growth, reducing DNA replication since the double helix ribbon presents increased stiffness. Aluminum toxicity alters enzyme mechanisms, results in polysaccharide accumulation, affects cellular respiration, and modifies the structure and function of the plasma membrane, which 
impairs the absorption of water and nutrients (Sheng, 2010; Patra et al., 2020). Effects of Al on shoot growth may be a secondary consequence that includes a reduction of photosynthesis (Vitorello et al., 2005; Ying \& Liu, 2005; Mihailovic, Drazic \& Vucinic, 2008; Lazarević, Horvat \& Poljak, 2014). Aluminum may hinder chloroplast formation and modify its function (Moustakas et al., 1997). As a result, there is a decrease in stomatal conductance and biochemical reactions of $\mathrm{CO}_{2}$ fixation (Vitorello et al., 2005; Mukhopadyay et al., 2012). Biotechnological approaches have contributed to understanding the effects of Al in plants along with the function and interaction of resistance genes (Kochian et al., 2015; Ryan, 2018; Patra et al., 2020). Aluminum induces the expression of different genes, like TaALMT1 in wheat, an Alactivated malate transporter (Sasaki et al., 2004); AtMATE, an Al-activated citrate transporter in Arabidopsis (Liu et al., 2009); ALS3 that redistributes Al accumulated away from sensitive tissues to protect the growing root from the toxic effects of Al; ALS1 in Arabidopsis that encodes a root tip and stele localized half type $\mathrm{ABC}$ transporter required for root growth in $\mathrm{Al}$ toxic environments (Larsen et al., 2005; Larsen et al., 2007); STAR1 and STAR2 that form a complex that functions as an $\mathrm{ABC}$ transporter, which is required for detoxification of $\mathrm{Al}$ in rice (Huang et al., 2009); SbMATE, an Al-activated citrate transporter in sorghum (Magalhães et al., 2007); HvAACT1 that secretes citrate to the rhizosphere in barley (Fujii et al., 2012); and ScFRDL2, involved in Al-activated citrate secretion in the rye (Yokosho, Yamaji \& Ma, 2010). There are several Al tolerance mechanisms involved in different biochemical pathways with one or more genes. They differ among species and even among cultivars of the same species. This difference is expected since plants may differ in Al mobilization capacity, absorption rate, nutritional requirements, Al resistance, and nutrient balance maintenance in acidic soils (Poschenrieder et al., 2008).

The quantitative molecular technique of qPCR has been widely used for gene expression analysis in Al tolerance studies. Gene expression response to $\mathrm{Al}$ was analyzed in maize regarding Zm.16676.1.A1 (putative cytochrome P450 superfamily protein), related to the control of both biosynthesis and inactivation of gibberellin; Zm.3634.1.A1 (jasmonate-induced protein), involved in jasmonate biosynthesis; Zm.6272.1.A1 (UDP-glycosyltransferase), involved in hormone biosynthesis, metabolism of secondary metabolite, and responses to stress and xenobiotics; and Zm.1228.2.A1 (PHG1A protein), involved in cellular adhesion in higher eukaryotes, (Mattiello et al., 2014). Genome-wide transcriptomic analyses have been used to examine buckwheat (Fagopyrum tataricum) for Al-tolerance mechanisms (Zhu et al., 2015). Studies have also looked at the ASRI and ASR5 genes in rice, as well as complementary transcription factors that regulate gene expression in response to Al (Arenhart et al., 2016).

Several genes are differentially regulated by Al stress in different plant species. In sugarcane, histone deacetylase (P56521), serine/threonine kinase (AP002482), and RAS-related protein RGP1 (P25766) have been described to have different expression pattern in presence of Al (Watt, 2003). Drummond et al. (2001) identified several genes with high similarity, including Superoxide dismutase $\mathrm{Cu}-\mathrm{Zn}$, and Phospholipid hydroperoxide glutathione peroxidase-like. 
117 These genes code enzymes that alleviate oxidative stress, or combat infection by pathogens like

118

119

120

121

122

123

124

125

126

127

128

129

130

131

132

133

134

135

136

137

138

139

140

141

142

143

144

145

146

147

148

149

150

151

152

153

154

155

156 War13.2 - oxalate oxidase and wali4 - phenylalanine ammonia-lyase, and genes that code for proteins responsible for the release of organic acids, Succinate-CoA ligase - beta chain and Malate dehydrogenase, and signal transducers, NtGDI1 - GDP dissociation inhibitor and SLT2 MAP - kinase. All of these genes are related to SAS 43.141 (Sugarcane Assembled Sequences) in sugarcane, which are available at SUCEST (Sugarcane EST Project - http://sucest-fun.org/ Vettore et al., 2001), including genes related to Al tolerance described in the literature. Differentially regulated genes have been identified in two sugarcane cultivars with more than 4,000 differentially expressed genes (DEGs) in the tolerant cultivar and only about 850 DEGs in the Al sensitive cultivar. Among several transcripts, the ARF (Auxin responds factor), MT1 (metallothionein-like protein 1), CDPK (calcium-dependent protein kinase), and Glutathione Stransferases genes were substantially active in Al tolerance mechanisms; ARF was related to auxin signaling, MTI to detoxification, CDPK to signal transduction, and Glutathione $S$ transferases it ROS protection mechanism (Rosa-Santos et al., 2020).

Sugarcane possesses one of the most complex plant genomes, presenting a level of polyploidy ranging from 5 to 16 (Hoang et al., 2015). The response of this crop to Al toxicity remains poorly understood ever since the pioneer study by Hetherington, Asher \& Blamey (1988) compared Al tolerance of three Australian sugarcane cultivars, Q77, Q113, and Q117, in a shortterm solution culture experiment. Studies on genes related to sugarcane tolerance to Al are scarce (Drummond et al., 2001; Watt, 2003). Gene expression patterns are determinants of physiological processes that can modify plants' cellular properties associated with stress (Rickes et al., 2019; Rosa-Santos et al., 2020). Determining gene expression patterns in response to Al stress could improve our understanding of their functions so that we can establish effective strategies to cope with stress conditions.

In this study, we present a physiological, nutritional, and molecular evaluation of Brazilian sugarcane cultivars. We examined nutrient and Al content in roots and in leaves, and physiological parameters as transpiration rate, stomatal conductance, photosynthesis, and chlorophyll content. Moreover, we performed a gene expression analysis of succinate dehydrogenase $(S D H)$, malate dehydrogenase $(M D H)$, and superoxide dismutase $(S O D)$.

\section{Materials \& Methods}

\section{Plant Material and Growth Conditions}

Experiments were carried out at the Agrarian Sciences Center of the Federal University of São Carlos (UFSCar), Araras-SP, Brazil (22 $2^{\circ} 1^{\prime} \mathrm{S}$ lat; 47²3' W long; $690 \mathrm{~m}$ altitude). According to Köppen's climatological classification, the regional climate is Cwa type (called tropical highland), mesothermic with warm and humid summer and dry winter. The average annual precipitation is $1,430 \mathrm{~mm}$ and the average annual temperature is $21.5^{\circ} \mathrm{C}$.

Three sugarcane cultivars were selected: RB928064 (medium cycle; high soil fertility potential), RB867515 (medium cycle; medium to low soil fertility potential), and RB935744 (late cycle; medium soil fertility potential) (RIDESA, 2010). Sugarcane mini-stalks were provided by the 
157 Sugarcane Genetic Improvement Program at UFSCar, which is a part of the Inter-University

158 Network for the Development of Sugar and Energy Sector. Sugarcane mini-stalks with one bud 159 were cut to a length of $6 \mathrm{~cm}$ and heat-treated $\left(52{ }^{\circ} \mathrm{C}\right.$ for $\left.20 \mathrm{~min}\right)$ to prevent chlorotic streak

160

161

162

163

164

165

166

167

168

169

170

171

172

173

174

175

176

177

178

179

180

181

182

183

184

185

186

187

188

189

190

191

192

193

194

195

196

197 disease and stimulate germination. The setts were then dipped in fungicide $(6.5 \%$ benomyl $)$ for $30 \mathrm{~s}$ and sprouted in plastic trays with medium-texture vermiculite as a substrate when dry [water: vermiculite ratio 1:0.8 (wt/wt)]. Stalk borders were previously sealed to avoid excessive oxidation and fungal contamination by dipping in hot paraffin wax (Hetherington, Asher \& Blamey, 1988).

The mini-stalks were placed in trays with the bud side up and covered with a thin layer of vermiculite. Trays were placed in a germination chamber at a constant temperature of $30^{\circ} \mathrm{C}$ and intermittent light photoperiod. The average pre-sprouting period was $15 \mathrm{~d}$ with some variation according to sugarcane cultivar. Substrate moisture was controlled daily with water replaced every $48 \mathrm{~h}$. These steps were performed for both greenhouse and nutritive-solution experiments.

\section{Greenhouse bioassay}

Subsoil samples (0.2-0.4 m) of Dystrophic Typic Hapludox (Oxisol) were collected in a sugarcane cultivation area at Santa Lucia Sugar and Alcohol Mill (southeast region of Brazil; 22 18 'S and $47^{\circ} 23^{\prime} \mathrm{W}$ ). Both chemical and physical analysis were performed on air-dried soil samples sorted in a $2 \mathrm{~mm}$ mesh sieve, following official Brazilian procedure (Raij et al., 2001; Camargo et al., 2009) that is aligned with well-known international methods of soil analysis (Sparks et al., 1996; Dane \& Topp, 2002). Soil $\mathrm{pH}_{\mathrm{CaCl} 2}$ was determined potentiometrically in $0.01 \mathrm{M} \mathrm{CaCl}_{2}(1: 2.5$ soil: solution ratio) using a combined glass calomel electrode. Soil organic matter was quantified by oxidation with potassium dichromate in the presence of sulfuric acid, followed by titration with ammonium $\mathrm{Fe}^{2+}$ sulfate (classical Walkley-Black method). P, K, Ca, and Mg content was extracted by the ion exchange resin method. $\mathrm{P}$ content was determined by photocolorimetry, $\mathrm{K}$ content by flame atomic emission spectrometry, and $\mathrm{Ca}$ and $\mathrm{Mg}$ content by atomic absorption spectroscopy (AAS). Exchangeable aluminum $\left(\mathrm{Al}^{3+}\right)$ was extracted with $1 \mathrm{M} \mathrm{KCl}$ solution and determined by titration with $0.025 \mathrm{M} \mathrm{NaOH}$. Soil potential acidity $(\mathrm{H}+\mathrm{Al})$ was extracted by $0.5 \mathrm{M}$ calcium acetate solution at $\mathrm{pH} 7.0$ and determined by titration with $0.025 \mathrm{M} \mathrm{NaOH}$. Total cation exchange capacity $[\mathrm{TCEC}=\mathrm{SB}+(\mathrm{H}+\mathrm{Al})]$ was obtained as the sum of exchangeable bases $(\mathrm{EB}=\mathrm{Ca}+\mathrm{Mg}+\mathrm{K})$ and soil potential acidity. Base saturation was obtained by $\mathrm{V} \%=(\mathrm{EB} / \mathrm{TCEC}) \times 100$, and aluminum saturation was calculated by $\mathrm{m} \%=(\mathrm{Al} / \mathrm{EB}+\mathrm{Al}) \times 100$. S content was extracted by $0.01 \mathrm{M} \mathrm{CaH}_{2} \mathrm{PO}_{4}$ solution and determined by turbidimetry. Boron content was extracted by hot water and determined by the azomethine-H method. $\mathrm{Cu}, \mathrm{Fe}, \mathrm{Mn}$, and $\mathrm{Zn}$ content was extracted by DTPA-TEA solution at pH 7.3 and determined by AAS. Clay, sand, and silt content was determined by the pipette method and the moisture at field capacity (FC) was determined at tensions of 6,10 , and $33 \mathrm{kPa}$. Soil samples were sorted into two treatments: a control group with the addition of limestone and an aluminum treatment group with aluminum chloride. Limestone was added at a dosage equivalent to $1.3 \mathrm{tha}^{-1}$ to a portion of the soil samples to increase the soil base saturation (V\%) to $60 \%$ for the adequate cultivation of sugarcane (Raij et al., 1996). Aluminum chloride

hexahydrate $\left(\mathrm{AlCl}_{3} \cdot 6 \mathrm{H}_{2} \mathrm{O}\right.$ - Synth $\left.{ }^{\circledR}\right)$ was added to another portion of the soil samples to increase 
198

199

200

201

202

203

204

205

206

207

208

209

210

211

212

213

214

215

216

217

218

219

220

221

222

223

224

225

226

227

228

229

230

231

232

233

234

235

236

237

the soil Al saturation ( $\mathrm{m} \%$ ) above $50 \%$ and induce $\mathrm{Al}$ stress. Soil samples incubated with limestone and those incubated with $\mathrm{AlCl}_{3} \cdot 6 \mathrm{H}_{2} \mathrm{O}$ were sieved again after 30 days. Soil columns were made by overlapping six rigid polyvinyl chloride (PVC) rings, which were attached externally using tape and special PVC adhesive. Each ring was $20 \mathrm{~cm}$ in diameter and $20 \mathrm{~cm}$ in height. The final height of each soil column was $1.2 \mathrm{~m}$. The columns were filled with soil up to $1.5 \mathrm{~cm}$ from the top edge, forming a soil column of $118.5 \mathrm{~cm}$ in height and containing $37.8 \mathrm{dm}^{3}$ of soil. The soil samples amended with limestone were used to fill the control columns and the first upper ring of the columns containing treatments with Al. This was done to provide conditions for good initial development of sugarcane stalks and to simulate the conditions of the arable layer (0.0-0.2 m) of cultivated soil.

After a pre-sprouting period, two stalks were transplanted into each soil column. At the end of one week, stalks that showed low development were removed. Each column initially received water pulses to maintain moisture and ensure the establishment of tillers. After the establishment period, soil moisture was maintained at $70 \%$ of field capacity, monitored by weighing. The experiment was conducted with a completely randomized design using five replicates for each treatment and cultivar, totalizing 30 columns.

Each column received plant fertilization (Raij et al., 1996) with $1.3 \mathrm{~g}$ of potassium chloride (58\% of $\left.\mathrm{K}_{2} \mathrm{O}\right), 2.35 \mathrm{~g}$ of simple superphosphate $\left(17 \%\right.$ of $\left.\mathrm{P}_{2} \mathrm{O}_{5}\right)$, and $0.24 \mathrm{~g}$ of ammonium sulfate $(21 \%$ of $\mathrm{N}$ ), based on chemical analysis of the soil (Table 1). In topdressing, fertilization was applied again using the same amount of $\mathrm{K}_{2} \mathrm{O}$ and $\mathrm{N} 30$ days after the transplant. The experiment was conducted for six months under greenhouse conditions. Physiological parameters [transpiration rate $\left(\mathrm{mmol} \mathrm{H}_{2} \mathrm{O} \mathrm{m}^{-2} \mathrm{~s}^{-1}\right)$, photosynthesis rate $\left(\mathrm{CO}_{2} \mu \mathrm{mol} \mathrm{m} \mathrm{m}^{-2} \mathrm{~s}^{-1}\right)$, and stomatal conductance $\left(\mathrm{H}_{2} \mathrm{O}\right.$ mol m-2 $\mathrm{s}^{-1}$ )] were analyzed using an infra-red gas analyzer (IRGA) with an airflow of $300 \mathrm{~mL}$ $\mathrm{min}^{-1}$ and a coupled light source of $995 \mathrm{mmol} \mathrm{m}^{-2} \mathrm{~s}^{-1}$ (ADC, model LCi, Hoddesdon, UK). The measurement was performed on the third fully expanded leaf, in the morning of the last week of the experiment (between 8:00 am and 10:00 am) for all experimental plants (total of 30 plants). At the end of the experiment, samples of plant tissue were collected to analyze nutrient and $\mathrm{Al}$ content in the leaves and roots, and for chlorophyll extraction. The last ring of each soil column was cut and washed to completely remove soil attached to the root system. The entire root volume of this ring was separated for further analysis. Leaf samples were collected according to the morphological description of the crop and the Kuijper system of leaf description.

Representative leaf samples of each treatment were formed by the central third of leaves +1 and +2 without the ribs for all replicates. Samples of roots and leaves were wrapped in labeled paper bags for transport to a forced-air oven and dried at $65^{\circ} \mathrm{C}$. Milling was carried out in Willey mills with knives, a stainless steel chamber, and sieves of $1 \mathrm{~mm}$ in diameter to ensure homogenization of the sample. Plant tissue samples were submitted to chemical analysis according to Malavolta et al. (1997). Root and leaf samples were subjected to solubilization with concentrated sulfuric acid, and the $\mathrm{N}$ content was determined by the semi-micro Kjeldahl method. To determine the $\mathrm{P}$, $\mathrm{K}, \mathrm{Ca}, \mathrm{Mg}, \mathrm{S}, \mathrm{Cu}, \mathrm{Fe}, \mathrm{Mn}$, and $\mathrm{Zn}$ content, samples were first solubilized with nitric (65\%) and perchloric acids (70\%). The $\mathrm{P}$ content was determined by vanadium-yellow spectrometry. The $\mathrm{K}$ 
238

239

240

241

242

243

244

245

246

247

248

249

250

251

252

253

254

255

256

257

258

259

260

261

262

263

264

265

266

267

268

269

270

271

272

273

274

275

276

content was determined by emission flame spectrometry at wavelengths between 766 and 767 $\mathrm{nm}$. The $\mathrm{Ca}, \mathrm{Mg}, \mathrm{Cu}, \mathrm{Fe}, \mathrm{Mn}$, and $\mathrm{Zn}$ content was determined by AAS with specific hollowcathode lamps for each element, and the S content was measured by turbidimetry using a UVVIS spectrometer. The remaining samples were incinerated in an electric muffle furnace at a temperature between 500 and $550^{\circ} \mathrm{C}$, and the resulting ash was dissolved in a $0.1 \mathrm{M}$ nitric acid solution. The resulting extract was used for the determination of $\mathrm{B}$ by the azomethine-H method. For Al determination, dry vegetable matter was also oxidized by incineration. Hydrochloric acid $(0.1 \mathrm{M})$ was added to the burned material, and the formed extract was treated with aluminon $(0.10 \%)$ (triammonium salt of aurintricarboxylic acid). Aluminon interacts with Al to form a complex, and the intensity of the developed color was measured using a spectrophotometer at $520 \mathrm{~nm}$ according to a standard curve with predetermined Al concentrations (Brauner, Catani \& Bittencourt, 1966).

Extractions of chlorophyll $a$, chlorophyll $b$, and total chlorophyll $(a+b)$ were performed using leaf fragment samples of the central third of diagnostic leaves +1 . For the analysis, $0.5 \mathrm{~g}$ of plant tissue was macerated with $5 \mathrm{~mL}$ of $80 \%$ acetone and filtered under vacuum. The final volume was adjusted to $50 \mathrm{~mL}$ with $80 \%$ acetone. The extracts were measured in a spectrophotometer to the read absorbance at wavelengths of $663 \mathrm{~nm}$ (chlorophyll $a$ ), $645 \mathrm{~nm}$ (chlorophyll $b$ ), and 652 $\mathrm{nm}$ [total chlorophyll $(a+b)]$. The chlorophyll content is expressed in $\mu \mathrm{g} \mathrm{g}^{-1}$ fresh sample mass according to the following equations (Eq. 1-3) (Carlin, Rhein \& Santos, 2012):

Chlorophyll $b=\left(\left(22.9 \times\left(\mathrm{A}_{645}\right)-4.68 \times\left(\mathrm{A}_{663}\right)\right) \times \frac{\mathrm{V}}{1000 \times \mathrm{W}}\right) \times 1000$

Total Chlorophyll $(\mathrm{a}+\mathrm{b})=\left(\frac{\left(\left(\mathrm{A}_{652}\right) \times 1000\right)}{34.5} \times \frac{\mathrm{V}}{1000 \times \mathrm{W}}\right) \times 1000$

Chlorophyll $a=\left(\left(12.7 \times\left(\mathrm{A}_{663}-2.69 \times\left(\mathrm{A}_{645}\right)\right) \times \frac{V}{1000 \times W}\right) \times 1000\right.$

$A=$ absorbance $(\mathrm{nm}) ; \mathrm{V}=$ final volume of the extract $(80 \%$ acetone + chlorophyll); $\mathrm{W}=$ fresh sample mass $(\mathrm{g})$.

The results were compared by analysis of variance (ANOVA), using the program StatSoft STATISTICA 7.0. Upon determining significance for the F test $(p<0.05)$, averages were compared using Tukey's test $(p<0.05)$.

\section{Nutritive Solution Analysis}

Mini-stalks with vigor and homogeneity were selected from the trays, fixed in styrofoam plates, and transferred to black receptacles $(34 \mathrm{~cm} \times 53 \mathrm{~cm} \times 13 \mathrm{~cm}$; capacity of $23.5 \mathrm{~L})$ containing $17 \mathrm{~L}$ of nutritive solution to avoid light exposure. Before applying Al stress, adequate mineral nutrition for the sugarcane mini-stalks was established using an adaptation of the classic solution from Hoagland and Arnon, which was prepared based on the foliar nutrient content considered suitable for sugarcane (Raij et al., 1996). Macro and micronutrient solutions were calculated for the sugarcane plants (Cometti et al., 2006), which had the following composition: (i) 
277 macronutrients $\left(\mathrm{g} \mathrm{L}^{-1}\right)$ - calcium nitrate $(0.407)$, potassium nitrate $(0.547)$, monoammonium

278

279

280

281

282

283

284

285

286

287

288

289

290

291

292

293

294

295

296

297

298

299

300

301

302

303

304

305

306

307

308

309

310

311

312

313

314

315

phosphate (0.181), and magnesium sulfate (0.150); (ii) micronutrients ( $\left.\mathrm{mg} \mathrm{L}^{-1}\right)$ - boric acid (0.30), copper sulfate $(0.15)$, iron sulfate (2.40), manganese sulfate (1.50), sodium molybdate (0.03), and zinc sulfate (0.15). The nutritive solution was used to guarantee full conditions of a balanced nutrient supply to the stalks, and especially the roots to prevent limitations that are not caused by Al stress.

Stalks were fixed on polystyrene boards for root system immersion. The set was maintained under aeration through a bubbling air motor compressor. Uninterrupted light incidence equivalent to 5000 lux was applied with a 40-W fluorescent light in FITOTRON® Plant Growth Chambers for $24 \mathrm{~h}$. After six days of immersion in nutritive solution, 30 mini-stalks with root uniformity were selected, representing 5 replicates for each cultivar and treatment. The stalks were placed in the holes of a polystyrene board and transferred to rigid polyvinyl chloride receptacles with $10 \mathrm{~cm}$ diameter and $20 \mathrm{~cm}$ height. The receptacles were filled with $2.7 \mathrm{~L}$ of nutritive solution, and two different $\mathrm{Al}$ concentrations were applied: 0 (control) and $3000 \mu \mathrm{mol}$ $\mathrm{L}^{-1}$, which were provided using aluminum chloride hexahydrate $\left(\mathrm{AlCl}_{3} \cdot 6 \mathrm{H}_{2} \mathrm{O}\right)$. The roots were exposed to $\mathrm{Al}$ solution for six days. The $\mathrm{pH}$ nutritive solution was adjusted daily to $4.0( \pm 0.2)$ with $0.1 \mathrm{~mol} \mathrm{~L}-1 \mathrm{HCl}$ to ensure the predominance of trivalent free species of $\mathrm{Al}\left[\mathrm{Al}\left(\mathrm{H}_{2} \mathrm{O}\right)_{6}{ }^{3+}\right]$ (Rossiello \& Jacob Neto, 2006). Fe was omitted from the solution to avoid interference, and $\mathrm{P}$ concentration was reduced to $0.0025 \mathrm{mmol} \mathrm{L}^{-1}$ due to issues with Al precipitation (Braccini et al., 2000).

\section{qPCR analysis}

Genes that have well-known or putative functions in the mechanism of aluminum tolerance (Vettore et al., 2001; Casu et al., 2004) were chosen for gene expression analysis using quantitative PCR (qPCR) (Bustin, 2009). Two independent experiments were performed to evaluate the gene expression of the $S D H, M D H$, and $S O D$ genes (Table 2) in the roots and shoots of three sugarcane cultivars exposed to aluminum. These genes were chosen for being related to Al tolerance. They have been described for other graminaceous crops that present high similarity with sugarcane. Root apex and shoot segments were collected from plants after 6 days of exposure to aluminum or to nutritive solution alone (non-treatment group). They were then immediately frozen in liquid nitrogen. Plant material was disrupted in liquid nitrogen with a mortar and pestle, and RNA was isolated using TRIzol reagent (Invitrogen) according to the manufacturer's instructions.

RNA quality was confirmed using agarose gel stained with ethidium bromide and visualized under UV light to evaluate the presence of intact 28S and 18S rRNA bands. RNA concentration and purity were measured using a Thermo Scientific NanoDrop 2000 spectrophotometer. Samples were treated with DNase I Amplification Grade (Invitrogen) to remove genomic DNA. DNAse treatment was validated by qPCR using polyubiquitin reference gene primer with the DNAse-treated RNA as a template for reactions. A total of $1.5 \mu \mathrm{g}$ of DNase-treated RNA was

PeerJ reviewing PDF | (2020:10:53435:2:0:NEW 13 Apr 2021) 
316

317

318

319

320

321

322

323

324

325

326

327

328

329

330

331

332

333

334

335

336

337

338

339

340

341

342

343

344

345

346

347

348

349

350

351

352

353

354

reverse transcribed with a High-Capacity cDNA Reverse Transcription kit (ThermoFisher Scientific) using 100 pmol of oligodTV. qPCR reactions were conducted using $2 \mu \mathrm{L}$ of cDNA, 1x Platinum SYBR Green qPCR SuperMix-UDG (Invitrogen), and final primer concentrations of $300 \mathrm{mM}$ for polyubiquitin (reference gene), $100 \mathrm{mM}$ for $S D H, 450 \mathrm{mM}$ for $M D H$ and $S O D$ in a final volume of $10 \mu \mathrm{L}$. Reactions were conducted in triplicate in an ECO Real-Time PCR system (Illumina) with the following conditions: $2 \mathrm{~min}$ at $50^{\circ} \mathrm{C}, 2 \mathrm{~min}$ at $95^{\circ} \mathrm{C}$, [40x] $95^{\circ} \mathrm{C}$ for $30 \mathrm{~s}, 55^{\circ} \mathrm{C}$ for $30 \mathrm{~s}$, and 72 ${ }^{\circ} \mathrm{C}$ for $40 \mathrm{~s}$. A melting curve was obtained after each reaction to confirm there were no nonspecific amplification products. The used primers are listed in Table 2, and the concentrations were optimized before the reaction efficiency analysis. Reactions had an amplification efficiency between 95 and 105\% and $\mathrm{R}^{2}>99 \%$. Data were analyzed using the $2^{-\Delta \Delta \mathrm{Ct}}$ method (Livak \& Schimittgen, 2001). Observed differences in gene expression were considered significant when $p$ was lower than 0.05 with a $95 \%$ confidence interval.

\section{Results}

\section{Greenhouse bioassay}

Soil incubation with limestone for $50 \mathrm{~d}$ resulted in the following chemical parameters: $\mathrm{pH}_{\mathrm{CaCl} 2}=$ 4.9 , potential acidity $(\mathrm{H}+\mathrm{Al})=20 \mathrm{mmol}_{\mathrm{c}} \mathrm{dm}^{-3}$, exchangeable $\mathrm{Al}=1 \mathrm{mmol}_{\mathrm{c}} \mathrm{dm}^{-3}, \mathrm{~EB}$ $($ exchangeable bases $)=22.7 \mathrm{mmol}_{\mathrm{c}} \mathrm{dm}^{-3}$, TCEC $\left(\right.$ total cation exchange capacity) $=74.0 \mathrm{mmol}_{\mathrm{c}}$ $\mathrm{dm}^{-3}, \mathrm{~V} \%$ (base saturation $)=53$ and $\mathrm{m} \%(\mathrm{Al}$ saturation $)=4.22$. Aluminum chloride was added to soil samples to induce stress by $\mathrm{Al}$ and the following results were obtained: $\mathrm{pH}_{\mathrm{CaCl} 2}=3.7$, $\mathrm{H}+\mathrm{Al}=58 \mathrm{mmol}_{\mathrm{c}} \mathrm{dm}^{-3}, \mathrm{Al}=21 \mathrm{mmol}_{\mathrm{c}} \mathrm{dm}^{-3}, \mathrm{~EB}=16 \mathrm{mmol}_{\mathrm{c}} \mathrm{dm}^{-3}, \mathrm{TCEC}=42.7 \mathrm{mmol}_{\mathrm{c}} \mathrm{dm}^{-3}$, $\mathrm{V} \%=22$ and $\mathrm{m} \%=56.76$.

\section{Nutrient content in roots and leaves}

The effect of $\mathrm{Al}$ and the influence of sugarcane cultivar were evaluated for roots and leaves separately. All results of leaf and root nutrient content significantly different by ANOVA F test $(p<0.05)$ were submitted to the Tukey's test $(p<0.05)$ (Figure 1). Interaction between sugarcane cultivars and Al levels was highly significant $(p<0.01)$ for the content of $\mathrm{N}, \mathrm{P}, \mathrm{K}, \mathrm{Mg}$, and $\mathrm{S}$ in the roots, and the content of $\mathrm{N}, \mathrm{P}$, and $\mathrm{K}$ in the leaves. The content of primary macronutrients $(\mathrm{N}$, $\mathrm{P}$, and $\mathrm{K}$ ) in the plant tissue was highly dependent on the interaction between cultivars and levels of $\mathrm{Al}$. Calcium content in the roots, and $\mathrm{Ca}$ and $\mathrm{Mg}$ content in leaves were highly significant $(p<0.01)$ for both isolated factors $(p<0.01)$ while $\mathrm{S}$ content was only attributed to the effect of the cultivars $(p<0.01)$.

The range of variation for nutrient content $\left(\mathrm{g} \mathrm{kg}^{-1}\right)$ in the roots were as follows: (i) control treatment - N 5.75-13.50; P 0.29-0.82; K 6.99-24.46; Ca 2.29-3.95; Mg 1.76-3.91; S 1.92-5.59; (ii) Al induced stress treatment - N 6.00-10.50; P 0.34-0.61; K 9.32-12.81; Ca 1.39-3.22; Mg 0.66-1.18; S 1.17-2.11. The nutrient content $\left(\mathrm{g} \mathrm{kg}^{-1}\right)$ in the leaves varied as follows: i) control treatment - N 13.93-18.91; P 0.90-1.07; K 8.15-13.12; Ca 3.54-5.74; Mg 1.80-2.73; S 1.17-2.10; 
355

356

357

358

359

360

361

362

363

364

365

366

367

368

369

370

371

372

373

374

375

376

377

378

379

380

381

382

383

384

385

386

387

388

389

390

391

392

393

394

(ii) $\mathrm{Al}$ induced stress treatment - N 14.10-17.33; P 0.77-1.24; K 8.15-11.10; Ca 3.10-4.35; Mg 1.53-2.19; S 1.15-1.78.

Nutrient levels in the plant tissue of cultivars cultivated in the control treatment were higher in most cases. RB928064 presented the greatest content of nutrients in the leaves and in the roots, regardless of treatment with $\mathrm{Al}$, confirming its high nutritional requirement (RIDESA, 2010). Cultivars RB928064 and RB935744 showed greater nutrient absorption when compared with RB867515, but they showed a decrease in the nutrient content after exposure to stress by Al. Even with a lower nutrient uptake (intrinsic characteristic of the cultivar) compared to other cultivars, RB867515 showed a different behavior, with a higher content of $\mathrm{N}, \mathrm{P}$, and $\mathrm{K}$ in induced Al stress treatment when compared to the control.

\section{Al content in roots and leaves}

Interaction between the factors sugarcane cultivar and Al level was not statistically significant to explain Al content in roots or leaves. Aluminum content in the roots was highly significant $(p<0.01)$ for both isolated factors. The levels of Al in leaves were only explained by the cultivar $(p<0.01)$ (Fig. 2).

The ranges of variation for $\mathrm{Al}$ content $\left(\mathrm{g} \mathrm{kg}^{-1}\right)$ in the roots were as follows: (i) control treatment from 418.57 (RB867515) to 433.07 (RB935744); (ii) Al induced stress treatment - from 426.91 (RB928064) to 544.95 (RB867515). The Al content ( $\left.\mathrm{g} \mathrm{kg}^{-1}\right)$ in the leaves varied as follows: i) control treatment - from 23.00 (RB867515) to 87.825 (RB928064); (ii) Al induced stress treatment - from 26.86 (RB867515) to 49.13 (RB928064).

The cultivar RB928064 presented the lowest Al content in the roots, followed by RB935744 and RB867515. There was no significant difference among them. Al content in the leaves and in the root did not follow the same trend. RB928064 had the highest Al content in the leaves compared to the other cultivars. Considering the cumulative total amount of Al in plant tissues (leaves + roots), RB928064 had the lowest content compared to the other cultivars (Fig. 2).

\section{Physiological parameters}

Photosynthesis rate was only explained by the cultivar $(p<0.01)$. Interaction between cultivars and Al levels explained rate of transpiration and stomatal conductance $(p<0.05)$. RB928064 and RB867515 showed nearly twice the accumulation of $\mathrm{CO}_{2}$ efficiency compared with RB935744. RB928064 showed the highest rate of transpiration and stomatal conductance when in control conditions. On the other hand, it presented lower rates of transpiration and conductance compared to the other studied cultivars when subjected to induced Al stress treatment (Fig. 3). Interaction between cultivar and Al level explained the content of chlorophyll $a(\mathrm{p}<0.05)$, chlorophyll $b(p<0.01)$, and total chlorophyll $(a+b)(p<0.01)$. In the control treatment, RB867515 had higher content of chlorophyll $a$ while RB935744 and RB928064 cultivars had higher levels of chlorophyll $b$ and $a+b$. The addition of Al did not cause a difference in the content of chlorophyll $a, b$ or $a+b$ among cultivars. Aluminum induced treatment resulted in a decrease of almost 50\% in the content of chlorophyll $a$ for RB867515 and chlorophyll $b$ content 
395

396

397

398

399

400

401

402

403

404

405

406

407

408

409

410

411

412

413

414

415

416

417

418

419

420

421

422

423

424

425

426

427

428

429

430

431

432

433

434

for RB867515 and RB935744 (Fig. 4). Regarding the content of chlorophyll $b$ and $a+b$, the stress induced by Al caused an increase in RB928064 and a decrease in RB935744 cultivars, but did not cause changes in RB867515 (Fig. 4).

\section{Gene expression analysis}

A statistically significant variation ( $\mathrm{t}$ test, $p<0.05$ ) in the expression of the $S O D, M D H$ and $S D H$ genes was observed with exposure of the cultivars to stress by Al (Fig. 5). The only change in the $S D H$ gene expression was observed in the roots of the cultivar RB928064, which decreased (0.35-fold) after the stress induced by Al (Fig 5A). The $M D H$ gene expression decreased (0.24fold) in the roots of cultivar RB935744 (Fig. 5B), and in the leaves (0.13-fold) of cultivar RB867515 (Fig. 5C). A high $M D H$ gene expression (3.35-fold) was observed in the roots of RB867515 (Fig 5C). The SOD gene expression was significant in the three cultivars, increasing equally in leaves (1.21-fold) and in roots (1.31) of cultivar RB928064 (Fig 5A). In cultivar RB935744, greater $S O D$ gene expression (2.74-fold) was observed in the leaves. In the roots, gene expression decreased (0.55-fold) (Fig. 5B). The inverse behavior was noticed for the cultivar RB867515, in which there was a decrease in the SOD gene expression (0.14-fold) in the leaves, and an increase (2.36) in the roots (Fig. 5C).

\section{Discussion}

Soil incubation with limestone for $50 \mathrm{~d}$ was enough to achieve proper chemical conditions for sugarcane cultivation: $\mathrm{V} \%$ close to 60 and low levels of exchangeable $\mathrm{Al}\left(1 \mathrm{mmol}_{\mathrm{c}} \mathrm{dm}^{-3}\right)$ and $\mathrm{m} \%(4.22 \%)$. Soils with great fertility problems have very high exchangeable Al content (higher than $3 \mathrm{mmol}_{\mathrm{c}} \mathrm{dm}^{3}$ ), as well as Al saturation ( $\mathrm{m} \%$ ) higher than $50 \%$. The $\mathrm{m} \%(56.76 \%)$ and exchangeable $\mathrm{Al}\left(21 \mathrm{mmol}_{\mathrm{c}} \mathrm{dm}^{-3}\right)$ values were high enough to guarantee a sufficient level of $\mathrm{Al}$ stress for the sugarcane cultivars to verify their behavior in response to high levels of Al in lowfertility soil (Table 1).

The treatment induced by Al caused a change in nutrient content in the plant tissues of the three cultivars. In root tissues, $\mathrm{N}, \mathrm{P}, \mathrm{Ca}$, and Mg concentrations were higher for the cultivar RB928064, while $\mathrm{K}$ and S content were higher for RB935744. The lowest levels of $\mathrm{N}$ and $\mathrm{Mg}$ were observed in the roots of the RB935744. Low root $\mathrm{P}, \mathrm{K}, \mathrm{Ca}$, and $\mathrm{Mg}$ content was also observed in RB967515 (Fig. 1). While Al decreased the absorption of nutrients by RB928064 and RB935744, there was an increase in N, P, and K root content in RB967515 under Al stress. RB928064 exhibited the highest $\mathrm{K}, \mathrm{Ca}, \mathrm{Mg}$, and $\mathrm{S}$ leaf content, and the lowest $\mathrm{N}$ and $\mathrm{P}$ content. The highest content of $\mathrm{N}, \mathrm{P}$, and $\mathrm{Mg}$ and the lowest content of $\mathrm{K}$ were observed in the leaves of RB935744. The highest nutrient content of cultivars RB928064 and RB935744 are probably due to the intrinsic characteristic of these cultivars as they are recommended in agricultural environments with greater soil fertility potential (RIDESA, 2010). The lowest content of $\mathrm{N}, \mathrm{K}$, $\mathrm{Ca}$, and $\mathrm{Mg}$ were observed in the leaves of RB967515. Despite having the highest Al (Fig. 2) and the lowest nutrient content in the tissues (Fig. 1), RB867515 showed greater resilience in nutrient content when submitted to Al stress (Fig. 1 - A, B and C). Its rusticity, recognized by its 
435

436

437

438

439

440

441

442

443

444

445

446

447

448

449

450

451

452

453

454

455

456

457

458

459

460

461

462

463

464

465

466

467

468

469

470

471

472

473

474

breeding program, allows its cultivation in more restrictive agricultural areas, and development in less fertile soils (RIDESA, 2010). Oliveira et al. (2010) demonstrated the wide variation in nutritional requirement for the production of one ton of stalk per hectare (TSH) in the irrigated cane-cycle of 11 Brazilian sugarcane cultivars. Sugarcane TSH ranged from 155 to $256 \mathrm{t} \mathrm{ha}^{-1}$, and wide nutrient extraction was observed $\left(0.53-1.27 \mathrm{~kg} \mathrm{t}^{-1}\right.$ of $\mathrm{N} ; 0.10-0.17 \mathrm{~kg} \mathrm{t}^{-1}$ of P; 0.83-2.58 $\mathrm{kg} \mathrm{t}^{-1}$ of $\mathrm{K} ; 0.92-1.52 \mathrm{~kg} \mathrm{t}^{-1}$ of Ca; $0.35-0.50 \mathrm{~kg} \mathrm{t}^{-1}$ of Mg). Maintaining or increasing nutrient absorption under stress by $\mathrm{Al}$ is a desired characteristic in sugarcane cultivars, since it contributes to lower the occurrence of damage to the cells and to the plant as a whole. The first Al contact with the plant occurs at the cell wall, where it is absorbed by mass flow, being mainly accumulated in the apoplast. The binding of $\mathrm{Al}^{3+}$ to the plasma membrane alters its negative surface. This induces depolarization, especially at the root apex, the most sensitive zone to Al as well as the most active (Gupta, Gaurav \& Kumar et al., 2013; Rao, 2016; Ryan, 2018; Yadav et al., 2020). These changes in plasma membrane properties affect both ion absorption and transport (Horst, Wang \& Eticha et al., 2010). Water and nutrients do not enter the cell with altered permeability, and the plant becomes more susceptible to drought and nutritional stress. This was observed in cells of maize roots subjected to Al, where changes in the cellular integrity of the root apex resulted in lower $\mathrm{Ca}, \mathrm{Mg}$, and $\mathrm{K}$ absorption (Wang et al., 2015). The decrease in the nutrient content in leaves and roots after exposure to Al was observed for the three sugarcane cultivars (Fig.1). There was an exception in the cultivar RB867515, which showed an increase in the root $\mathrm{P}$ and $\mathrm{K}$ content in response to stress by $\mathrm{Al}$.

The Al content in the roots and leaves was consistent with previous reports for sugarcane (Watt, 2003). The cultivar RB928064 presented the lowest Al content in the roots, followed by

RB935744 and RB867515, which did not differ significantly from each other. Aluminum content in the leaves and in the root did not follow the same trend. RB928064 had the lowest total amount of $\mathrm{Al}$ in plant tissues (leaves + roots) compared to other cultivars (Fig. 2) but the highest Al content in the leaves (Fig 2). The greatest Al leaf content of RB928064 (Fig. 2) can be due to transporter activity that acts on the plasma membrane, removing Al from the negative sites of the root's apoplast. Aluminum is bound to organic acid, transported by the xylem, and then forms a complex for leaf storage by vacuolar compartmentalization (Kochian et al., 2015; Wang et al., 2015; Bojórquez-Quintal, 2017). Aluminum has no phytotoxic effect on the plant once bound to organic acid and compartmentalized in a cell structure by this accumulation mechanism (Kochian et al., 2015; Yan et al., 2021). This decreases the level of toxic Al that would cause cellular rupture and impair root growth (Klug \& Horst, 2010). In contrast to species or cultivars that accumulate $\mathrm{Al}$, some plants use a less specialized exclusion mechanism of intraradicular and extracellular compartmentalization (Kochian et al., 2015). Apparently, RB935744 and

RB867515 cultivars use this mechanism as suggested by the higher concentrations of Al in the root tissue. More specific studies to identify the metabolic routes of Al detoxification may clarify specialized mechanisms employed by sugarcane cultivars.

Regarding stomatal conductance and transpiration rate, RB935744 and RB967515 cultivars proved unresponsive to induced Al stress. RB928064 has presented higher stomatal conductance 
475

476

477

478

479

480

481

482

483

484

485

486

487

488

489

490

491

492

493

494

495

496

497

498

499

500

501

502

503

504

505

506

507

508

509

510

511

512

513

514

and transpiration rate than other cultivars in control conditions, parameters that were reduced by half in the presence of $\mathrm{Al}$ (Fig. 3 - A and B). An indirect effect of Al phytotoxicity is the decrease in water use efficiency resulting from damages to the root system. In the absence of chemical (phytotoxicity by Al) or physical (compaction) soil impediments, root system growth of sugarcane under field conditions can exceed $4 \mathrm{~m}$ in depth (Laclau \& Laclau, 2009), or even 6 $\mathrm{m}$ in depth (Smith et al., 2005). The average root system depth of sugarcane cultivated in the Brazilian Cerrado conditions (savanna) is estimated at $0.6 \mathrm{~m}$ due to high soil Al saturation and low levels of Ca, among other factors (Koffler, 1986). The absence of a well-developed and wellfunctional root system decreases stomatal conductance, transpiration rate, internal $\mathrm{CO}_{2}$ concentration, and photosynthesis rate (Basnayake et al., 2015; Ferreira et al., 2017). The decreased transpiration rate and stomatal conductance of RB928064 (Fig. 3 - A and B) indicates that the plant has increased susceptibility to water stress as a response to the presence of Al. The sensitivity of these parameters was even observed when there was no water deprivation in our study. Aluminum stress tolerant cultivars tend to be more water-efficient and produce more dry matter per gram of transpired water. Even though water stress was not the focus of our study, these results may guide future studies on water use efficiency of sugarcane cultivars.

There was no decrease in content of chlorophyll $a$, chlorophyll $b$, and total chlorophyll $(a+b)$ for the RB928064 cultivar treated with Al. The presence of Al greatly increased the content of chlorophyll $b$ and total chlorophyll $(a+b)$ for RB928064. Content of chlorophyll $a$ in the leaves of RB867515 decreased with Al addition (Fig. 4). However, the RB928064 and RB867515 cultivars had higher photosynthesis rates than RB935744 (Fig. 3 - C), and the decrease in chlorophyll content does not seem to have proportionally affected photosynthesis rate. The rate of $\mathrm{CO}_{2}$ assimilation by plants may vary according to species and even among cultivars, depending on factors such as plant age, Al concentration, and the time of exposure to Al (Fonseca Júnior et al., 2014). Particularly for cultivar RB867515, the lowest chlorophyll content was associated with the lowest foliar levels of $\mathrm{N}$ and $\mathrm{Mg}$ (Fig. 1 - F). Chlorophyll molecules are formed by complexes derived from porphyrin, with a central $\mathrm{Mg}$ atom. Nitrogen is directly linked to the synthesis of chlorophyll- $a$ that is used in the first stage of photosynthesis (photosystem I) (Taiz \& Zeiger, 2001).

Damages from $\mathrm{Al}$ in the photosynthetic process of sugarcane plants are associated to $\mathrm{Al}$ interference in both energy absorption and electron transfer processes in photosystem II; this component of the photosynthetic complex plays an essential role on the response to environmental stress and when chlorophyll $b$ predominates (Ecco, Santiago \& Lima, 2013). Greater photosynthetic efficiency of RB867515 is probably more closely associated with the content of chlorophyll $b$, which was not negatively affected by the presence of Al (Fig. 4). Gene expression analysis showed that the highest $M D H$ gene expression of RB867515 (3.35fold) was in the roots (Fig 5C). This gene is responsible for the reversible reduction of oxaloacetate to malate. In plants, malate is involved in respiration, nutrient absorption, stomatal movement, nitrogen assimilation, and photosynthesis (Vance \& Heicher, 1991). Some studies even discuss the relationship between the production of organic acids (succinic acid, citric acid, 
515 malic acid, and oxalic acid) and $M D H$ gene expression. When $M D H$ gene is overexpressed, there 516 is an increase in organic acid exudation, which increases Al tolerance (Tesfaye et al., 2001;

517 Wang et al., 2010). High $M D H$ gene expression suggests organic acids are involved in

518 mechanisms of Al detoxification used by RB867515. The higher Al content in the root tissue

519 (Fig. 2) may have triggered a higher expression of these genes after the absorption of Al by the

520 root. Organic acids act through $\mathrm{Al}$ chelation to maintain $\mathrm{Al}$ in the root apoplast, in the root

521 symplasm, or in the cell walls of the root. The exposure to stress by Al decreased $M D H$ gene

522 expression in the roots of RB935744 (Fig. 5B), and in the leaves of RB867515 (Fig. 5C). Most

523 studies with Al in plants only analyze the root system, but a differential expression of genes that

524 participate in the Krebs Cycle and are related to the production of organic acids, such as $M D H$,

525 have been reported in leaves. In the transcriptome analysis, 668 DEGs were found in the leaves,

526 number that is significantly higher than those reported for maize roots (Mattiello et al., 2010).

527 The $S O D$ gene is related to oxidative stress and showed increased leaf or root expression for all

528 cultivars (Fig. 5). Aluminum is highly reactive and alters the functions of the plasma membrane

529 and interacts with the phospholipid layer, causing peroxidation and an increase in toxic reactive

530 oxygen radicals (ROS) (Panda, Baluska \& Matsumoto, 2009). The family of antioxidant

531 superoxide dismutase (SOD) enzymes is the most effective in preventing cell damage in plants

532 caused by oxidative stress; it is present in all cells of all plants (Wang et al., 2016). The cultivar

533 RB928064 showed an equitable increase in SOD gene expression in the roots and leaves (Fig

534 5A). For the RB935744 cultivar, there was an increase in leaf $S O D$ expression and a decrease in

535 root $S O D$ expression (Fig 5B). The opposite pattern was observed for the cultivar RB867515,

536 with a decrease of $S O D$ expression in the leaves and an increase in $S O D$ expression in the roots

537 (Fig. 5C). The effect of gene expression related to SOD is governed by subcellular sites found in

538 tissue cells where oxidative stress is generated (Wang et al., 2016). The literature shows an

539 indistinct behavior of $S O D$ expression in the roots and leaves of several cultivated grasses. In

540 rice, the Al-tolerant Vandana cultivar presented lower ROS production in roots and leaves, as

541 well as increased SOD gene expression in these tissues in response to Al treatment compared to

542 the Al-sensitive cultivar HUR-105 (Bhoomika, Pyngrope \& Dubey, 2013). In rye, higher Al

543 accumulation, ROS, and cell death occurred in the Al-sensitive cultivar Riodeva compared to the

544 Al-tolerant Petkus, along with lower SOD gene expression in the roots. Petkus, however, showed

545 greater expression in roots than in leaves (Sánchez-Parra et al., 2015). A similar behavior was

546 observed in ryegrass (Cartes et al., 2012). These results corroborate with data observed in the

547 present study, where variation in the $S O D$ gene expression in tissues within the same species

548 may occur according to the inherent Al tolerance (or sensitivity).

549 The only change in $S D H$ gene expression was observed in the roots of the cultivar RB928064,

550 which decreased after the stress induced by Al (Fig 5A). The succinate dehydrogenase has a

551 central role in mitochondrial metabolism, acting in the tricarboxylic acid (TCA) cycle and in the

552 aerobic respiratory chain. It catalyzes the oxidation of succinate to fumarate and the reduction of

553 ubiquinone to ubiquinol (Figueroa et al., 2001). 
554

555

556

557

558

559

560

561

562

563

564

565

566

567

568

569

570

571

572

573

574

575

576

577

578

579

580

581

582

583

584

585

586

587

588

589

590

591

592

593

Up-regulation of expression in response to Al stress was observed in root tissues for the SOD gene in RB928064 (Fig. 5 A) and for $M D H$ gene in RB867515 (Fig. 5 C). In leaf tissues, the same was observed for SOD gene in RB928064 (Fig. 5 A) and RB935744 (Fig. 5 B). There was a higher frequency of down-regulation of gene expression under induced Al stress, noticed for $S D H$ gene in the root tissue of RB928064 (Fig. 5 A), $M D H$ and SOD genes in the root tissues of RB935744 (Fig. 5 B), and for $M D H$ and SOD genes in the leaf tissues of RB867515 (Fig. 5 C). Recently, Rosa-Santos et al. (2020) reported in RB855453 (Al-sensitive) and CTC-2 (Al-tolerant) cultivars that genes related to the auxin signaling, detoxification, ROS protection, and signal transduction were significantly involved in sugarcane response roots to Al.

\section{Conclusions}

The results of this study add to the demand for experiments to determine the role and gene expression related to Al stress in sugarcane. Gene expression of $M D H, S D H$ (both related to the production of organic acids), and SOD (related to oxidative stress) was evaluated by qPCR. Complimentary evaluations for practical application in agronomic purposes have also been proposed, such as changes in nutritional and physiological parameters in response to Al stress. Brazilian sugarcane RB867515, RB928064, and RB935744 cultivars exhibited very different response patterns to stress by Al. Exposure to Al caused up-regulation of gene expression in root (SOD gene in RB928064) and leaf tissues (SOD gene in RB928064, and $M D H$ gene in RB928064 and RB935744). Aluminum stress induced down-regulation of gene expression in both root (SDH gene in RB928064 and $M D H$ and SOD genes in RB935744) and leaf tissues ( $M D H$ and $S O D$ genes in RB867515). This investigation provides insights on Al detoxification mechanisms employed by sugarcane cultivars. Regarding gene expression, the cultivar RB867515 uses mechanisms of exclusion of Al by the production of organic acids in the roots while RB928064 seems to employ a mechanism of transport and accumulation of Al in the leaves. The sugarcane cultivar RB867515 was considered more Al-tolerant based on the following results: same content of primary macronutrients $(\mathrm{N}, \mathrm{P}$, and $\mathrm{K})$ in the leaves and roots regardless of the level of stress by $\mathrm{Al}$; highest $\mathrm{Al}$ content in the roots; lack of effect on rates of photosynthesis, transpiration and stomatal conductance by Al stress; gene expression of both $M D H$ and SOD in the roots. The RB928064 and RB935744 decreased nutrient content in the leaves and roots after exposure to $\mathrm{Al}$ and exhibited the lowest $\mathrm{Al}$ content in leaves + roots. Aluminum also decreased photosynthesis in RB935744 and the transpiration and stomatal conductance in RB928064. Finally, RB928064 showed only low expression of SOD in roots and leaves, while RB935744 showed important expression of the SOD gene only in leaves.

Regarding Al-tolerance, the sugarcane cultivars were classified as the following:

RB867515>RB928064=RB935744.

These findings may contribute to the selection of potential plants for breeding programs and for the development of cultivars better adapted to acidic soils. In addition, Al-tolerant cultivars enable a more sustainable agricultural system as they have lower requirements for soil input and are less susceptible to water stress due to the full development of the root system. 
594

595

596

597

598

599

600

601

602

603

604

605

606

607

608

609

610

611

612

613

614

615

616

617

618

619

620

621

622

623

624

\section{References}

Acompanhamento da safra brasileira de cana-de-açúcar - Safra 2020/21. Brasília: Conab, v.7., 62 p. https://www.conab.gov.br/info-agro/safras/cana/boletim-da-safra-de-cana-de-acucar

Adami M, Theodor Rudorff BF, Freitas RM, Aguiar DA, Sugawara LM. 2012. Remote sensing time series to evaluate direct land use change of recent expanded sugarcane crop in Brazil. Sustainability 4: 574-585 DOI: https://doi.org/10.3390/su4040574

Arenhart RA, Schunemann M, Bucker Neto L, Margis R, Wang ZY, Margis-Pinheiro M. 2016. Rice ASR1 and ASR5 are complementary transcription factors regulating aluminium responsive genes. Plant, Cell \& Environment 39:645-651. DOI: https://doi.org/10.1111/pce.12655

Arruda MR, Giller KE, Slingerland M. 2017. Where is sugarcane cropping expanding in the brazilian cerrado, and why? A case study. Anais da Academia Brasileira de Ciências 89:24852493 DOI: https://doi.org/10.1590/0001-3765201720150260.

Basnayake J, Jackson PAN, Inman-Bamber NG, Lakshmanan P. 2015. Sugarcane for waterlimited environments. Variation in stomatal conductance and its genetic correlation with crop productivity. Journal of Experimental Botany 66:3945-3958 DOI:

https://doi.org/10.1093/jxb/erv194

Bhoomika K, Pyngrope S, Dubey RS. 2013. Differential responses of antioxidant enzymes to aluminum toxicity in two rice (Oryza sativa L.) cultivars with marked presence and elevated activity of Fe SOD and enhanced activities of Mn SOD and catalase in aluminum tolerant cultivar. Plant Growth Regulation 71:235-252 DOI: https://doi.org/10.1007/s10725-013-9824-5

Bojórquez-Quintal E, Escalante-Magaña C, Echevarría-Machado I, Martínez-Estévez. 2017. Aluminum, a friend or foe of higher plants in acid soils. Frontiers in Plant Science 8:1767 DOI: https://doi.org/10.3389/fpls.2017.01767 
625 Bordonal RO, Carvalho JLN, Lal R, Figueiredo EB, Oliveira BG, La Scala Jr N. 2018.

626 Sustainability of sugarcane production in Brazil. A review. Agronomy for Sustainable

627 Development 38:13 DOI: https://doi.org/10.1007/s13593-018-0490-x

628

629 Braccini MCL, Martinez HEP, Silva EAM, Braccini AL, Scapim CA. 2000. Crescimento da

630 planta e coloração das raízes com hematoxilina como critérios de avaliação de genótipos de café

631 quanto à tolerância à toxidez por alumínio. Revista Brasileira de Ciência do Solo 24:59-68 DOI:

632 https://doi.org/10.1590/S0100-06832000000100008

633

634 Brauner JL, Catani RA, Bittencourt WC. 1966. Extração e determinação do alumínio trocável do 635 solo. Anais da Escola Superior de Agricultura “Luiz de Queiroz” 23:53-73 DOI:

636 https://doi.org/10.1590/S0071-12761966000100006

637

638

Bustin SA. 2009. The MIQE Guidelines: minimum information for publication of quantitative 639 real-time PCR experiments. Clinical Chemistry 55:411-422 DOI:

640 https://doi.org/10.1373/clinchem.2008.112797

641

642 Camargo OA, Moniz AC, Jorge JA, Valadares JMAS. 2009. Métodos de análise química, 643 mineralógica e física de solos do Instituto Agronômico de Campinas, first ed. Instituto 644 Agronômico, Campinas.

645

646 Carlin SD, Rhein AFL, Santos DMM. 2012. Efeito simultâneo da deficiência hídrica e do 647 alumínio tóxico no solo na cultivar IAC91-5155 de cana-de-açúcar. Semina-Ciências Agrárias 648 33:553-564. DOI: http://dx.doi.org/10.5433/1679-0359.2012v33n2p553

649

650 Cartes P, McManus M, Wulff-Zottele C, Leung S, Gutiérrez-Moraga A, Mora ML. 2012.

651 Differential superoxide dismutase expression in ryegrass cultivars in response to short term 652 aluminum stress. Plant and Soil 350:353-363 DOI: https://doi.org/10.1007/s11104-011-0919-3

653

654 Casu RE, Dimmock CM, Chapman SC, Grof CPL, McIntyre CL, Bonnet GD, Manners JM.

655 2004. Identification of differentially expressed transcripts from maturing stem of sugarcane by in 
656 silico analysis of stem expressed sequence tags and gene expression profiling. Plant Molecular

657 Biology 54:503 DOI: https://doi.org/10.1023/B:PLAN.0000038255.96128.41

658

659 Cometti NN, Furlani PR, Ruiz HR, Fernandes-Filho EI. 2006. Soluções nutritivas: formulações e 660 aplicações. In: Fernandes MS, ed. Nutrição Mineral de Plantas. Viçosa: Sociedade Brasileira de 661 Ciência do Solo, 89-114.

662

663

Dane JH, Topp CG. 2002. Methods of soil analysis: Part 4 - Physical methods. Book Series 5.4. 664 Madison: Soil Science Society of America.

665

Drummond RD, Guimarães, CT, Felix J., Ninamango-Cárdenas, FE, Carneiro, NP, Paiva, E, 667 Menossi, M. 2001. Prospecting sugarcane genes involved in aluminum tolerance. Genetics and 668 Molecular Biology 24:221-230 DOI: https://doi.org/10.1590/S1415-47572001000100029

669

Ecco M, Santiago EF, Lima PR. 2013. Chlorophyll a fluorescence in two varieties of sugarcane subjected to aluminum and water stress. African Journal of Agricultural Research, 8:4941-4948.

FAO - Food and Agriculture Organization of the United Nations. FAOSTAT. FAO, Rome. 2018. Available at http://www.fao.org/faostat/en/\#data/QC (accessed 18 March 2020).

Ferreira THS, Tsunada MS, Bassi D, Araújo P, Mattiello L, Guidelli GV, Righetto, Gonçalves VR, Lakshmanan P, Menossi M. 2017. Sugarcane water stress tolerance mechanisms and its implications on developing biotechnology solutions. Frontiers in Plant Science 8:1077 DOI:

679 https://doi.org/10.3389/fpls.2017.01077

680

681 Figueroa P, León G, Elorza A, Holuigue L, Jordana X. 2001. Three different genes encode the 682 iron-sulfur subunit of succinate dehydrogenase in Arabidopsis thaliana. Plant Molecular Biology 683 46:241-50 DOI: https://doi.org/10.1023/A:1010612506070 684

685 Filoso S, Carmo JB, Mardegan SF, Lins SRM, Gomes TF, Martinelli LA. 2015. Reassessing the 686 environmental impacts of sugarcane ethanol production in Brazil to help meet sustainability 
687 goals. Renewable and Sustainable Energy Reviews 52:1847-1856. DOI:

688 https://doi.org/10.1016/j.rser.2015.08.012

689

690 Fonseca Júnior EM., Cambraia J, Ribeiro C, Oliva MA, Oliveira JA, DaMatta FM. 2014. The

691 effects of aluminum on the photosynthetic apparatus of two rice cultivars. Experimental

692 Agriculture 50:343-352. DOI: https://doi.org/10.1017/S0014479713000471

693

694 Fujii M, Yokosho K, Yamaji N, Saisho D, Yamane M, Takahashi H, Sato K, Nakazono M, Ma

695 JF. 2012. Acquisition of aluminium tolerance by modification of a single gene in barley. Nature

696 Communications 3:713. DOI: https://doi.org/10.1038/ncomms1726

697

698 Furtado A, Lupoi JS, Hoang NV, Healey A, Singh S, Simmons BA, Henry RJ. 2014. Modifying

699 plants for biofuel and biomaterial production. Plant Biotechnology Journal 12:1246-1258 DOI:

700 https://doi.org/10.1111/pbi.12300

701

702 Gupta N, Gaurav SS, Kumar A. 2013. Molecular basis of aluminum toxicity in plants: a review.

703 American Journal of Plant Sciences 4:21-37 DOI:

704 http://dx.doi.org/10.4236/ajps.2013.4.12A3004

705

706

707

Hetherington SJ, Asher CJ, Blamey FPC. 1988. Comparative tolerance of sugarcane, navybean, soybean and maize to aluminum toxicity. Australian Journal of Agricultural Research 39:171-

708 176 DOI: https://doi.org/10.1071/AR9880171

709

710

Hoang NV, Furtado A, Botha FC, Simmons BA, Henry RJ. 2015. Potential for genetic

711 improvement of sugarcane as a source of biomass for biofuels. Frontiers in Bioengineering and

712

Biotechnology 3:182 DOI: https://doi.org/10.3389/fbioe.2015.00182

713

714 Horst WJ, Wang Y, Eticha D. 2010. The role of the root apoplast in aluminium-induced

715 inhibition of root elongation and in aluminium resistance of plants: a review. Annals of Botany

716 106:185-197 DOI: https://doi.org/10.1093/aob/mcq053

717 
718 Huang CF, Yamaji N, Mitani N, Yano M, Nagamura Y, Jiang FM. 2009. A bacterial-type ABC

719 transporter is involved in aluminum tolerance in rice. The Plant Cell 21:655-667 DOI:

720 https://doi.org/10.1105/tpc.108.064543

721

722 Klug B, Horst WJ. 2010. Spatial characteristics of aluminium uptake and translocation in roots

723 of buckwheat (Fagopyrum esculentum Moench). Physiologia Plantarum, 139:181-191. DOI:

724 https://doi.org/10.1111/j.1399-3054.2010.01355.x

725

726 Kochian LV, Piñeros MA, Liu J, Magalhães JV. 2015. Plant adaptation to acid soils: the

molecular basis for crop aluminum resistance. Annual Review of Plant Biology 66:571-598. DOI:

728 https://doi.org/10.1146/annurev-arplant-043014-114822

729

730

731

Koffler NF. 1986. A profundidade do sistema radicular e o suprimento de água às plantas no Cerrado. Piracicaba: Potafos.

732

733

734

Laclau PB, Laclau JP. 2009. Growth of the whole root system for a plant crop of sugarcane

735

under rainfed and irrigated environments in Brazil. Field Crops Research 114:351-360 DOI:

https://doi.org/10.1016/j.fcr.2009.09.004

736

737

Larsen PB, Cancel J, Rounds M, Ochoa V. 2007. Arabidopsis ALS1 encodes a root tip and stele

738

localized half type $\mathrm{ABC}$ transporter required for root growth in an aluminum toxic environment.

739

Planta 225:1447-1458 DOI: https://doi.org/10.1007/s00425-006-0452-4

740

Larsen PB, Geisler MJ, Jones CA, Williams KM, Cancel JD. 2005. ALS3 encodes a phloem-

742

localized $\mathrm{ABC}$ transporter-like protein that is required for aluminum tolerance in Arabidopsis.

743

The Plant Journal 41:353-363 DOI: https://doi.org/10.1111/j.1365-313X.2004.02306.x

Liu J, Magalhães JV, Shaff J, Kochian LV. 2009. Aluminum-activated citrate and malate 
750 Livak KJ, Schimittgen TD. 2001. Analysis of relative gene expression data using real-time

751 quantitative PCR and the 2- $\Delta \Delta \mathrm{CT}$. Methods 25:4 DOI: https://doi.org/10.1006/meth.2001.1262

752

753 Lazarević B, Horvat T, Poljak M. 2014. Effect of acid aluminous soil on photosynthetic

754 parameters of potato (Solanum tuberosum L.). Potato Research 57: 33-46 DOI:

755 https://doi.org/10.1007/s11540-014-9251-7

756

757 Magalhães JV, Liu J, Guimarães CT, Lana UGP, Alves VMC, Wang YH, Schaffert RE, 758 Hoekenga OA, Piñeros MA, Shaff JE, Kleins PE, Carneiro NP, Coekho CM, Trick HN, Kochian

759 LV. 2007. A gene in the multidrug and toxic compound extrusion (MATE) family confers

760 aluminum tolerance in sorghum. Nature Genetics 39:1156-1161 DOI:

761 https://doi.org/10.1038/ng2074

762

763

Malavolta E, Vitti GC, Oliveira SA. 1997. Avaliação do estado nutricional das plantas:

764 princípios e aplicações. 2. ed. rev. e atual. Piracicaba: Potafos.

765

766

Mattiello L, Begcy K, Silva FR, Jorge RA, Menossi M. 2014. Transcriptome analysis highlights

767

changes in the leaves of maize plants cultivated in acidic soil containing toxic levels of $\mathrm{Al}^{3+}$.

768

Molecular Biology Reports 41:8107-8116 DOI: https://doi.org/10.1007/s11033-014-3709-1

769

770

Mattiello L, Kirst M, Silva FR, Jorge RA, Menossi M. 2010. Transcriptional profile of maize

771

roots under acid soil growth. BMC Plant Biology 10:196 DOI: https://doi.org/10.1186/1471-

$772 \underline{2229-10-196}$

773

774

Mihailovic N, Drazic G, Vucinic Z. 2008. Effects of aluminum on photosynthetic performance in

Al-sensitive and Al-tolerant maize inbred lines. Photosynthetica 46:476-480 DOI:

776

https://doi.org/10.1007/s11099-008-0082-0

777

778 Mukhopadyay M, Bantawa P, Das A, Sarkar B, Bera B, Ghosh P, Mondal TK. 2012. Changes of 779 growth, photosynthesis and alteration of leaf antioxidative defence system of tea [Camellia 
780 sinensis (L.) O. Kuntze] seedlings under aluminum stress. Biometals 25:1141-1154 DOI:

781 https://doi.org/10.1007/s10534-012-9576-0

782

783

Moustakas MEP. Eleftheriou EP, Ouzounidou G. 1997. Short-term effects of aluminium at

784

alcaline $\mathrm{pH}$ on the structure and function of the photosynthetic apparatus. Photosynthetica 34:

785

169-177 DOI: https://doi.org/10.1023/A:1006880205108

786

787

Oliveira ECA, Freire FJ, Oliveira RI, Freire MBGS, Simões Neto DE, Silva SAM. 2010.

788

Extração e exportação de nutrientes por variedades de cana-de-açúcar cultivadas sob irrigação

789

plena. Revista Brasileira de Ciência do Solo 34:1343-1352 DOI: https://doi.org/10.1590/S0100-

790

$\underline{06832010000400031}$

791

792

Oliveira M. 2012. Tolerância de variedades de cana-de-açúcar (Saccharum spp.) à toxidez por

793

alumínio em solução. M. Sc. Thesis, Universidade Federal de São Carlos. Available at

794

https://repositorio.ufscar.br/handle/ufscar/8

795

796

Panda SK, Baluska F, Matsumoto H. 2009. Aluminum stress signaling in plants. Plant Signaling

797

\& Behavior 4:592-597 DOI: https://doi.org/10.4161/psb.4.7.8903

798

799

Patra A, Rekwar RK, Dutta A, Chatoopadhyay A. 2020. Toxicity of aluminum on plants

800

physiological and metabolic functions. Food and Scientific Reports 1:29-32.

801

802

Poschenrieder C, Gunsé B, Corrales I, Barceló J. 2008. A glance into aluminum toxicity and

803 resistance in plants. Science of the Total Environment 400:356-368 DOI:

804

https://doi.org/10.1016/j.scitotenv.2008.06.003

805

806

Raij B, Andrade JC, Cantarella H, Quaggio JA. 2001. Análise química para avaliação da

807

fertilidade de solos tropicais. Instituto Agronômico, Campinas.

808

809

Raij B, Cantarella H, Quaggio JA, Furlani AMC. 1996. Recomendações de adubação e calagem 810

para o Estado de São Paulo. Instituto Agronômico, Campinas. 
811

812 Rao IM, Miles JW, Beebe SE, Horst WJ. 2016. Root adaptations to soils with low fertility and

813 aluminum toxicity. Annals of Botany 118:593-605 DOI: https://doi.org/10.1093/aob/mcw073

814

815 RIDESA - Rede Interuniversitária para o Desenvolvimento do Setor Sucroalcooleiro. 2010.

816 Catálogo Nacional de Variedades “RB” de Cana-de-Açúcar. Ridesa, Curitiba.

817

818 Ribeiro AP, Souza WR, Martins PK, Vinecky F, Duarte KE, Basso MF, Cunha BADB,

819 Campanha RB, de Oliveira PA, Centeno DC, Cançado GMA, de Magalhães JV, de Souza CAF, 820 Andrade AC, Kobayashi AK, Molinari HBC. 2017. Overexpression of BdMATE gene improves

821 aluminum tolerance in Setaria viridis. Frontiers in Plant Science 8:1-12 DOI:

822 https://doi.org/10.3389/fpls.2017.00865

823

824

Rickes LN, Klumb EK, Benitez LC, Braga EJB, Bianchi VJ. 2019. Differential expression of the 825 genes involved in responses to water-deficit stress in peach trees cv. Chimarrita grafted onto two

826 different rootstocks. Bragantia 78:60-70 DOI: https://doi.org/10.1590/1678-4499.2017372

827

828

829

Rosa-Santos TM, da Silva RG, Kumar P, Kottapalli P, Crasto C, Kottapalli KR, França SC, Zingaretti SM. 2020. Molecular mechanism underlying sugarcane response to aluminum stress

830 by RNA-Seq. International Journal of Molecular Sciences 21:1-17 DOI:

831 doi:10.3390/ijms21217934

832

833

Rossiello ROP, Jacob Netto J. 2006. Toxidez de alumínio em plantas: novos enfoques para um velho problema. In: Fernandes MS, ed. Nutrição Mineral de Plantas. Viçosa: Sociedade Brasileira de Ciência do Solo, 375-418.

836

Ryan PR. 2018. Assessing the role of genetics for improving the yield of Australia's major grain 838 crops on acid soils. Crop \& Pasture Science 69:242-264 DOI: https://doi.org/10.1071/CP17310 839 
840 Sade H, Meriga B, Surapu V, Gadi J, Sunita MSL, Suravajhala P, Kishor PBK. 2016. Toxicity

841 and tolerance of aluminum in plants: tailoring plants to suit to acid soils. BioMetals 29:187-210

842 DOI: https://doi.org/10.1007/s10534-016-9910-Z

843

844 Sales CRG, Ribeiro RV, Hayashi AH, Marchiori PER, Silva KI, Martins MO, Silveira JAG,

845 Silveira NM, Machado EC. 2018. Flexibility of C4 decarboxylation and photosynthetic plasticity

846 in sugarcane plants under shading. Environmental and Experimental Botany 149:34-42 DOI:

847 https://doi.org/10.1016/j.envexpbot.2017.10.027

848

849 Sánchez-Parra B, Figueiras AM, Abd El-Moneim D, Contreras R, Rouco R, Gallego FJ, Benito

850 C. 2015. The role of two Superoxide dismutase mRNAs in rye aluminium tolerance. Plant

851 Biology 17:694-702 DOI: $\underline{\text { https://doi.org/10.1111/plb.12281 }}$

852

853 Sasaki T, Yamamoto Y, Ezaki B, Katsuhara M, Ahn SJ, Ryan PR, Delhaize E, Matsumoto H.

854 2004. A wheat gene encoding an aluminum-activated malate transporter. The Plant Journal

855 37:645-653 DOI: https://doi.org/10.1111/j.1365-313X.2003.01991.x

856

857 Singh S, Tripathi DK, Singh S, Sharma S, Dubey NK, Chauhan DK, Vaculík M. 2017. Toxicity

858 of aluminium on various levels of plant cells and organism: a review. Environmental and

859 Experimental Botany 137:177-193 DOI: https://doi.org/10.1016/j.envexpbot.2017.01.005

860

861 Sparks DL, Page AL, Helmke PA, Loeppert RH. 1996. Methods of soil analysis: Part 3 -

862 Chemical methods. Book Series 5.3. Madison: Soil Science Society of America.

863

864 Smith DM, Inman-Bamber NG, Thorburn PJ. 2005. Growth and function of the sugarcane root

865 system. Field Crops Research 92:169-183 DOI: https://doi.org/10.1016/j.fcr.2005.01.017

866

867 Taiz L, Zeiger E. 2001. Fisiologia Vegetal. Artmed, Porto Alegre.

868 
869 Tesfaye M, Temple SJ, Allan DL, Vance CP, Samac DA. 2001. Overexpression of malate

870 dehydrogenase in transgenic alfalfa enhances organic acid synthesis and confers tolerance to

871 aluminum. Plant Physiology 127:1836-1844 DOI: https://doi.org/10.1104/pp.010376

872

873 Vance CP, Heicher GH. 1991. Carbon in $\mathrm{N}_{2}$ fixation: limitation or exquisite adaptation. Annual

874 Review of Plant Physiology and Plant Molecular Biology 42:373-390 DOI:

875 https://doi.org/10.1146/annurev.pp.42.060191.002105

876

877 Vettore AL, Silva FR, Kemper EL, Arruda P. 2001. The libraries that made SUCEST. Genetics

878 and Molecular Biology 24:1-7 DOI: https://doi.org/10.1590/S1415-47572001000100002

879

880 Viana RS, Moreira BRA, Nogueira TAR, Figueiredo PAM, Teixeira Filho MCM, Ramo SB.

881 2020. Morphological changes in sugarcane crop induced by the plant growth-promoting

882 bacterium Azospirillum brasilense. Sugar Tech 22:241-249 DOI:

883 https://doi.org/10.1007/s12355-019-00773-2

884

885 Vitorello VA, Capaldi FR, Stefanuto VA. 2005. Recent advances in aluminum toxicity and 886 resistance in higher plants. Brazilian Journal of Plant Physiology 17:129-143 DOI:

887 https://doi.org/10.1590/S1677-04202005000100011

888

889

890 Wang L, Fan XW, Pan JL, Huang ZB, Li YZ. 2015. Physiological characterization of maize

891 tolerance to low dose of aluminum, highlighted by promoted leaf growth. Planta 242:1391-1403

892 DOI: https://doi.org/10.1007/s00425-015-2376-3

893

894 Wang QF, Zhao Y, Yi Q, Li KZ, Yu YX, Chen LM. 2010. Overexpression of malate

895 dehydrogenase in transgenic tobacco leaves: enhanced malate synthesis and augmented Al-

896 resistance. Acta Physiologiae Plantarum 32:1209-1220 DOI: https://doi.org/10.1007/s11738-

$897 \quad$ 010-0522-X

898 
899 Wang W, Xia MX, Chen J, Yuan R, Deng FN, Shen FF. 2016. Gene expression characteristics 900 and regulation mechanisms of superoxide dismutase and its physiological roles in plants under 901 stress. Biochemistry (Moscow) 81:465-480 DOI: https://doi.org/10.1134/S0006297916050047 902

903 Watt DA. 2003. Aluminum-responsive genes in sugarcane: identification and analysis of 904 expression under oxidative stress. Journal of Experimental Botany 54:1163-1174 DOI:

905 https://doi.org/10.1093/jxb/erg128

906

907

Yadav DS, Jaiswal B, Gautam M, Agrawal M. 2020. Soil acidification and its impact on plants.

908

In: Singh P, Singh SK, Prasad SM, ed. Plant Responses to Soil Pollution. India: Springer Nature

909 Singapore Pte Ltd., 1- 22. DOI: https://doi.org/10.1007/978-981-15-4964-9

910

911

Yamada T. 2005. The Cerrado of Brazil: a success story of production on acid soils. Soil Science

912 \& Plant Nutrition 51:617-620 DOI: https://doi.org/10.1111/ j.1747-0765.2005.tb00076.x

913

914

Yan L, Riaz M, Liu J, Yu, Cuncang J. 2021. The aluminum tolerance and detoxification

915 mechanisms in plants; recent advances and prospects. Critical Reviews in Environmental Science and Technology DOI: https://doi.org/10.1080/10643389.2020.1859306

917

918

Yokosho K, Yamaji N, Ma JF. 2010. Isolation and characterization of two MATE genes in rye.

919 Functional Plant Biology 37:296-303 DOI: https://doi.org/10.1071/FP09265

920

921 Ying XF, Liu P. 2005. Effects of aluminum stress on photosynthetic characters of soybean.

922 Chinese Journal of Applied Ecology 16:166-170 PMID: 15852980

923

924 Zheng SJ. 2010. Crop production on acidic soils: overcoming aluminum toxicity and phosphorus

925 deficiency. Annals of Botany 106:183-184 DOI: https://doi.org/10.1093/aob/mcq134

926

927 Zhu H, Wang H, Zhu Y, Zou J, Zhao FJ, Zhu CFH. 2015. Genome-wide transcriptomic and

928 phylogenetic analyses reveal distinct aluminum-tolerance mechanisms in the aluminum- 
929 accumulating species buckwheat (Fagopyrum tataricum). BMC Plant Biology 15:16 DOI:

930 https://doi.org/10.1186/s12870-014-0395-z 


\section{Table $\mathbf{1}$ (on next page)}

Chemical and physical attributes of subsoil samples from Dystrophic Typic Hapludox.

$\mathrm{OM}=$ organic matter $\mathrm{H}+\mathrm{Al}=$ soil potential acidity; $\mathrm{EB}=$ exchangeable bases; $\mathrm{TCEC}=$ total cation exchange capacity; $\mathrm{V} \%=$ base saturation; $\mathrm{m} \%=$ aluminum saturation; $\mathrm{FC}=$ moisture at field capacity. 
1 Table 1

2 Chemical and physical attributes of subsoil samples from Dystrophic Typic Hapludox.

\begin{tabular}{|c|c|c|c|c|c|c|c|c|c|c|c|}
\hline Depth & $\mathbf{P}_{\text {Resin }}$ & OM & pH & $\mathbf{K}$ & $\mathrm{Ca}$ & $\mathrm{Mg}$ & $\mathbf{H}+\mathbf{A l}$ & Al & EB & TCEC & $\mathbf{V}$ \\
\hline (m) & $\begin{array}{l}\text { mg } \\
\mathbf{d m}^{-3}\end{array}$ & $\begin{array}{l}\mathbf{g} \\
\mathbf{d m}^{-}\end{array}$ & $\mathrm{CaCl}_{2}$ & ---. & & 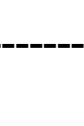 & --. & $\operatorname{mol}_{\mathbf{c}}$ & $m^{-3}$ & & $\%$ \\
\hline $\begin{array}{l}0,2- \\
0,4\end{array}$ & 4 & 7 & 4,2 & 0,2 & 7 & 3 & 24 & 4,1 & 10 & 34 & 29,4 \\
\hline Depth & $\mathrm{m} \%$ & $\mathbf{S}$ & B & $\mathbf{C u}$ & $\mathbf{F e}$ & Mn & $\mathbf{Z n}$ & Clay & Sand & Silt & FC \\
\hline (m) & $\%$ & --- & . & $---\mathbf{m}$ & $\mathrm{dm}$ & & ---- & -------- & ----- $g$ & $\mathrm{~kg}^{-1}$ & $\begin{array}{l}\mathrm{m}^{3} \\
\mathrm{~m}^{-3}\end{array}$ \\
\hline $\begin{array}{l}0,2- \\
0,4\end{array}$ & 29,1 & 57 & 0,01 & 0,3 & 14 & 1,7 & 0,6 & 160 & 790 & 50 & 0.30 \\
\hline
\end{tabular}

$3 \mathrm{OM}=$ organic matter; $\mathrm{H}+\mathrm{Al}=$ soil potential acidity; $\mathrm{EB}=$ exchangeable bases; $\mathrm{TCEC}=$ total cation

4 exchange capacity; $\mathrm{V} \%=$ base saturation; $\mathrm{m} \%=$ aluminum saturation; $\mathrm{FC}=$ moisture at field 5 capacity.

6 


\section{Table 2 (on next page)}

Selection of genes for qPCR analysis in Brazilian sugarcane cultivars.

F: Forward; R: Reverse 


\section{Table 2}

2 Selection of genes for qPCR analysis in Brazilian sugarcane cultivars.

\begin{tabular}{|c|c|c|c|c|c|c|}
\hline ene & Organism & Gene Bank & Description & Group & Reference & Sequence $5^{\prime}-3^{\prime}$ \\
\hline $\mathrm{SDH}$ & $\begin{array}{l}\text { Saccharum } \\
\text { hybrid } \\
\text { cultivar } \\
\text { Q117 }\end{array}$ & CF576911.1 & $\begin{array}{l}\text { Succinate } \\
\text { dehydrogenase }\end{array}$ & $\begin{array}{l}\text { Organic } \\
\text { acids }\end{array}$ & $\begin{array}{l}\text { Casu et } \\
\text { al.(2004) }\end{array}$ & $\begin{array}{l}\text { (F) TGCATCACCAAGCTCTTTC } \\
\text { (R) CCACCTCCAATCATCTTCAC }\end{array}$ \\
\hline$M D H$ & $\begin{array}{l}\text { Saccharum } \\
\text { hybrid } \\
\text { cultivar } \\
\text { SP803280 }\end{array}$ & CA119663.1 & $\begin{array}{l}\text { Malate } \\
\text { dehydrogenase }\end{array}$ & $\begin{array}{l}\text { Organic } \\
\text { acids }\end{array}$ & $\begin{array}{l}\text { Vettore et } \\
\text { al.(2001) }\end{array}$ & $\begin{array}{l}\text { (F) } \\
\text { CTTGATGTAATGAGGGCAAATAC } \\
\text { (R) } \\
\text { AGGAGTGGGAGTAATCGTAAG }\end{array}$ \\
\hline$S O D$ & $\begin{array}{l}\text { Saccharum } \\
\text { hybrid } \\
\text { cultivar } \\
\text { SP803280 }\end{array}$ & CA148508.1 & $\begin{array}{l}\text { Superoxide } \\
\text { dismutase } / \mathrm{Cu}- \\
\mathrm{Zn}\end{array}$ & $\begin{array}{l}\text { Oxidative } \\
\text { stress }\end{array}$ & $\begin{array}{l}\text { Vettore et } \\
\text { al.(2001) }\end{array}$ & $\begin{array}{l}\text { (F) AACCCCGATGGTAAAACACA } \\
\text { (R) AAGGTGGCAGTTCCATCATC }\end{array}$ \\
\hline POLI & & & Polyubiquitin & $\begin{array}{l}\text { Reference } \\
\text { gene }\end{array}$ & $\begin{array}{l}\text { Papini- } \\
\text { Terzi et al. } \\
(2005)\end{array}$ & $\begin{array}{l}\text { (F) } \\
\text { CCCTCTGGTGTACCTCCATTTG } \\
\text { (R) } \\
\text { CCGGTCCTTTAAACCAACTCAGT }\end{array}$ \\
\hline
\end{tabular}

F: Forward; R: Reverse 


\section{Figure 1}

Roots and leaves mean content of primary and secondary macronutrients in sugarcane cultivars cultivated in Dystrophic Typic Hapludox at different levels of Al stress

(control: soil Al content $=1 \mathrm{mmol}_{\mathrm{c}} \mathrm{dm}^{-3}$ and Al saturation $\mathrm{m} \%=4.22$; induced Al stress: soil

Al content $=21 \mathrm{mmol}_{\mathrm{c}} \mathrm{dm}^{-3}$ and Al saturation $\left.\mathrm{m} \%=56.76\right)$. Significant results for the interaction between sugarcane cultivars and Al levels (ANOVA F test; $p<0.05$ ): (A) Nitrogen (N) contents in roots and leaves; (B) Phosphorus (P) in roots and leaves; (C) Potassium (K) in roots and leaves; (D) Magnesium (Mg) in roots; (E) Sulfur (S) in roots; significant results only for sugarcane cultivars (ANOVA F test; $p<0.05$ ): (F) Calcium (Ca) in roots and leaves, and Mg and $\mathrm{S}$ in leaves. The standard error (SE) is represented in the figure by error bars attached to each column. Lowercase compares treatments for each cultivar and uppercase compares varieties for each treatment according to the Tukey's test, $p<0.05$; DW: dry weight. 

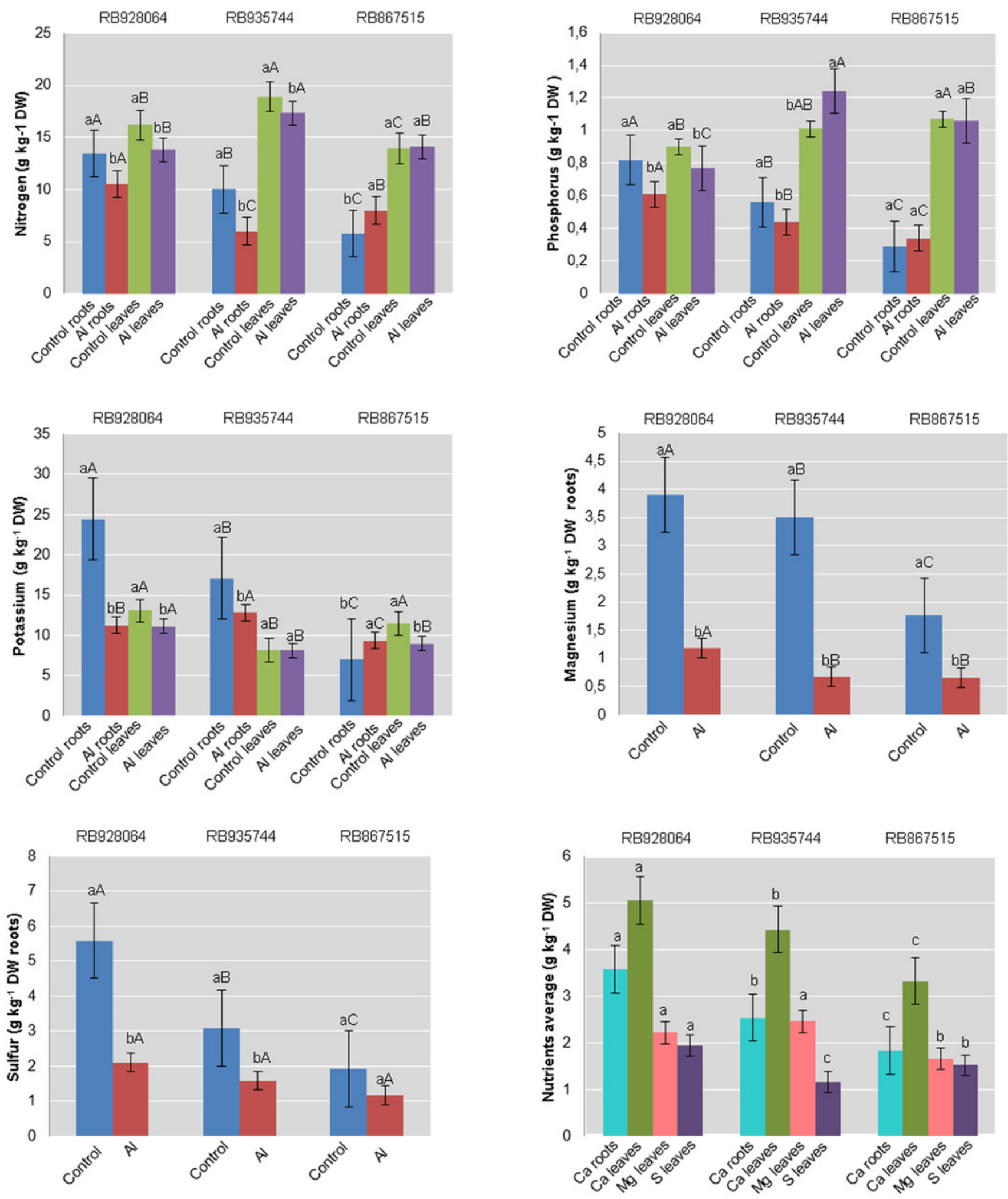


\section{Figure 2}

Aluminum (Al) mean content in roots and leaves of sugarcane cultivars cultivated in Dystrophic Typic Hapludox at different levels of Al stress

(control: soil Al content $=1 \mathrm{mmol}_{\mathrm{c}} \mathrm{dm}^{-3}$ and Al saturation $\mathrm{m} \%=4.22$; induced Al stress: soil Al content $=21 \mathrm{mmol}_{\mathrm{c}} \mathrm{dm}^{-3}$ and Al saturation $\mathrm{m} \%=56.76$ ); significant results only for sugarcane cultivars (ANOVA F test; $p<0.05$ ). The standard error (SE) is represented in the figure by error bars attached to each column. Uppercase letters compare Al content among cultivars for the same material (root or leaves) according to Tukey's test, $p<0.05$. 


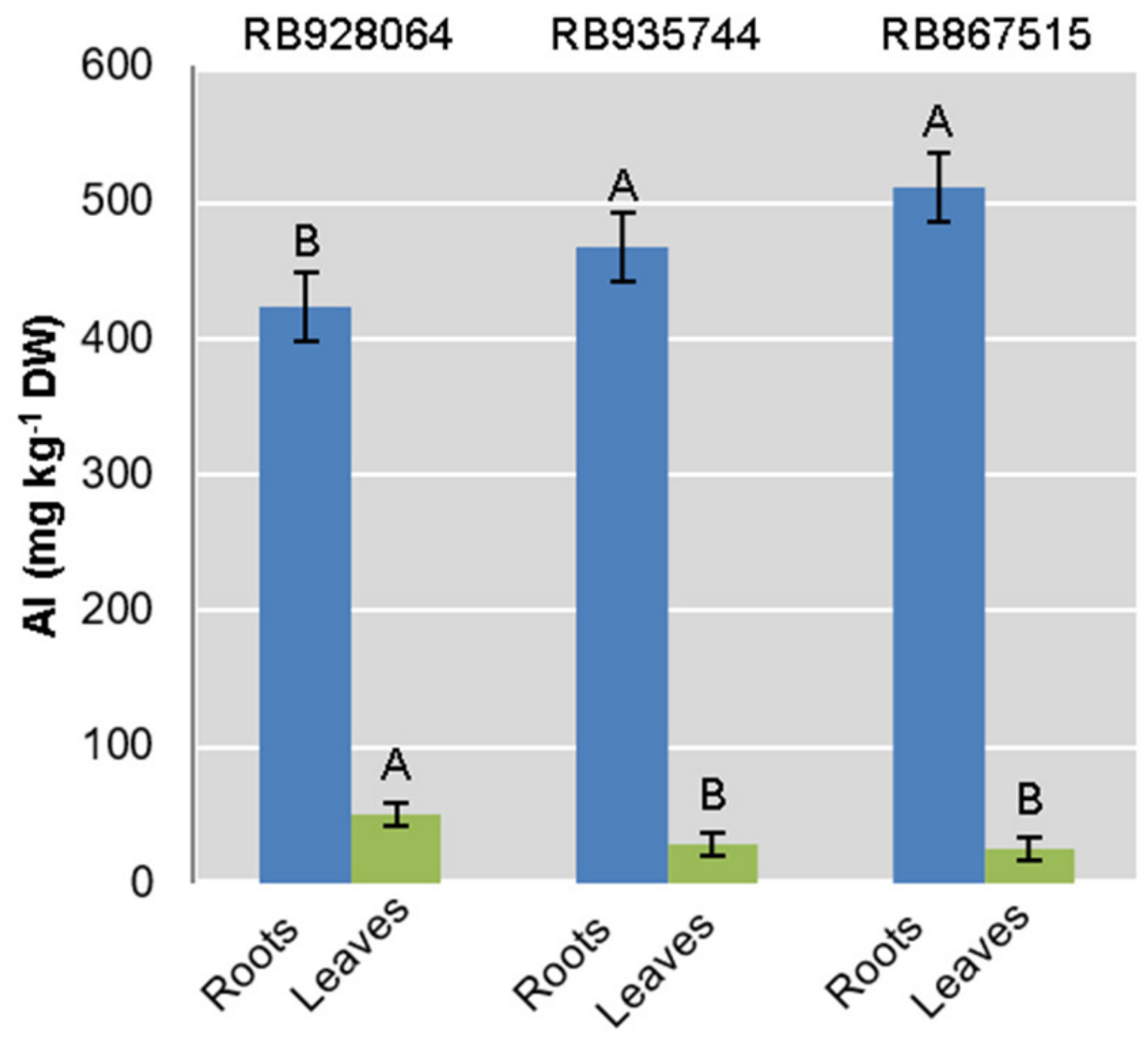




\section{Figure 3}

Physiological parameters (mean values) analyzed in leaves of sugarcane cultivars cultivated in Dystrophic Typic Hapludox at different levels of Al stress.

(control: soil Al content $=1 \mathrm{mmol}_{\mathrm{c}} \mathrm{dm}^{-3}$ and Al saturation $\mathrm{m} \%=4.22$; induced Al stress: soil

Al content $=21 \mathrm{mmol}_{\mathrm{c}} \mathrm{dm}^{-3}$ and Al saturation $\left.\mathrm{m} \%=56.76\right)$; significant results for the interaction between sugarcane cultivars and Al levels (ANOVA F test; $p<0.05$ ): (A) Stomatal conductance; (B) Transpiration; significant results only for sugarcane cultivars (ANOVA F test; $p<0.05$ ): (C) Photosynthetic rate. The standard error (SE) is represented in the figure by error bars attached to each column. Lowercase compares treatments for each cultivar and uppercase compares cultivars for each treatment according to Tukey's test, $p<0.05$. 

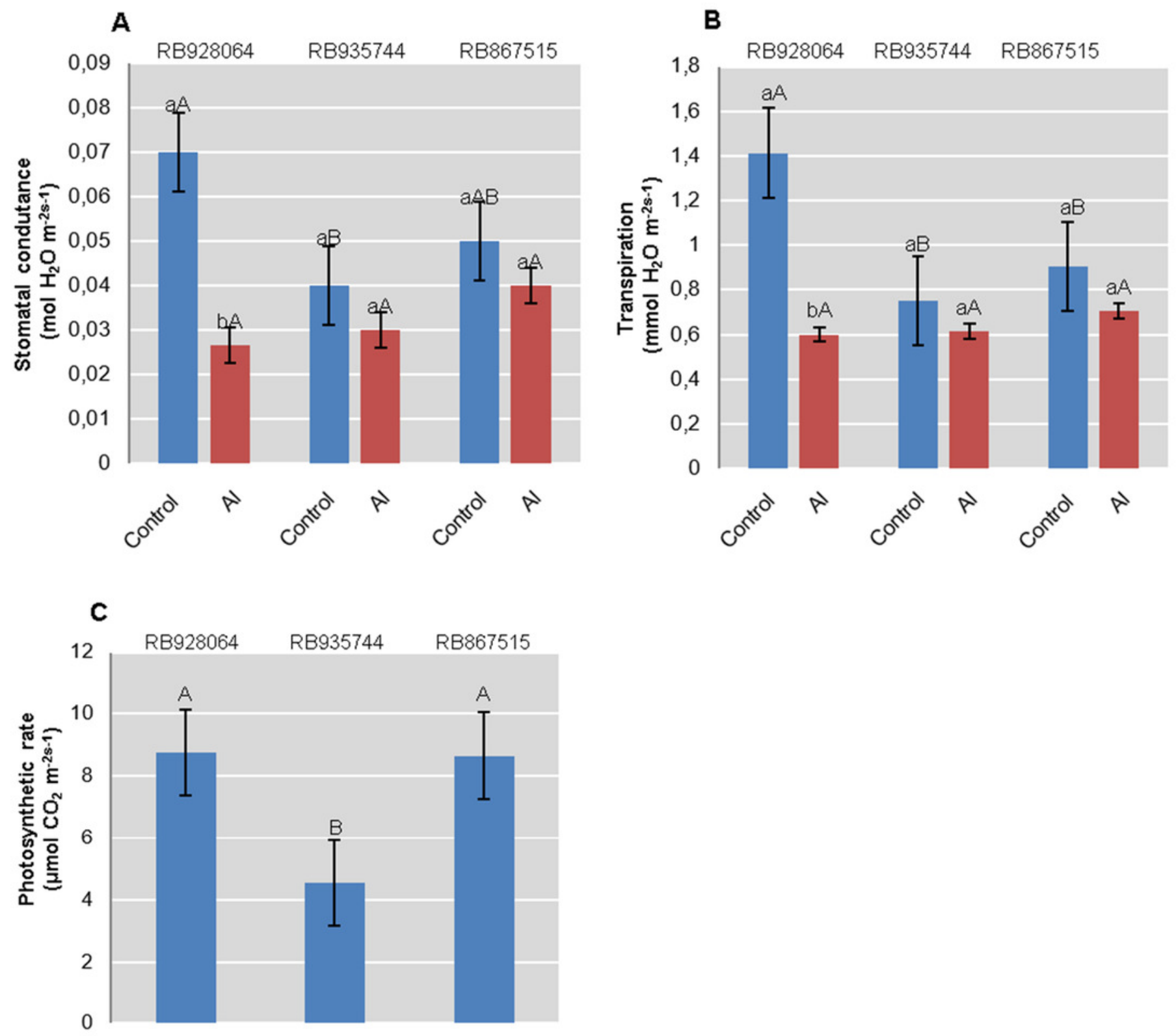


\section{Figure 4}

Chlorophylls mean content in leaves of sugarcane cultivars cultivated in Dystrophic Typic Hapludox at different levels of Al stress

(control: soil Al content $=1 \mathrm{mmol}_{\mathrm{c}} \mathrm{dm}^{-3}$ and Al saturation $\mathrm{m} \%=4.22$; induced Al stress: soil

Al content $=21 \mathrm{mmol}_{\mathrm{c}} \mathrm{dm}^{-3}$ and Al saturation $\left.\mathrm{m} \%=56.76\right)$. Significant results for the interaction between sugarcane cultivars and Al levels (ANOVA F test; $p<0.05$ ). The standard error (SE) is represented in the figure by error bars attached to each column Lowercase compares treatments for each cultivar for each type of chlorophyll and uppercase compares varieties for each type of chlorophyll according to Tukey's test, $p<0.05$; FW: fresh weight. 


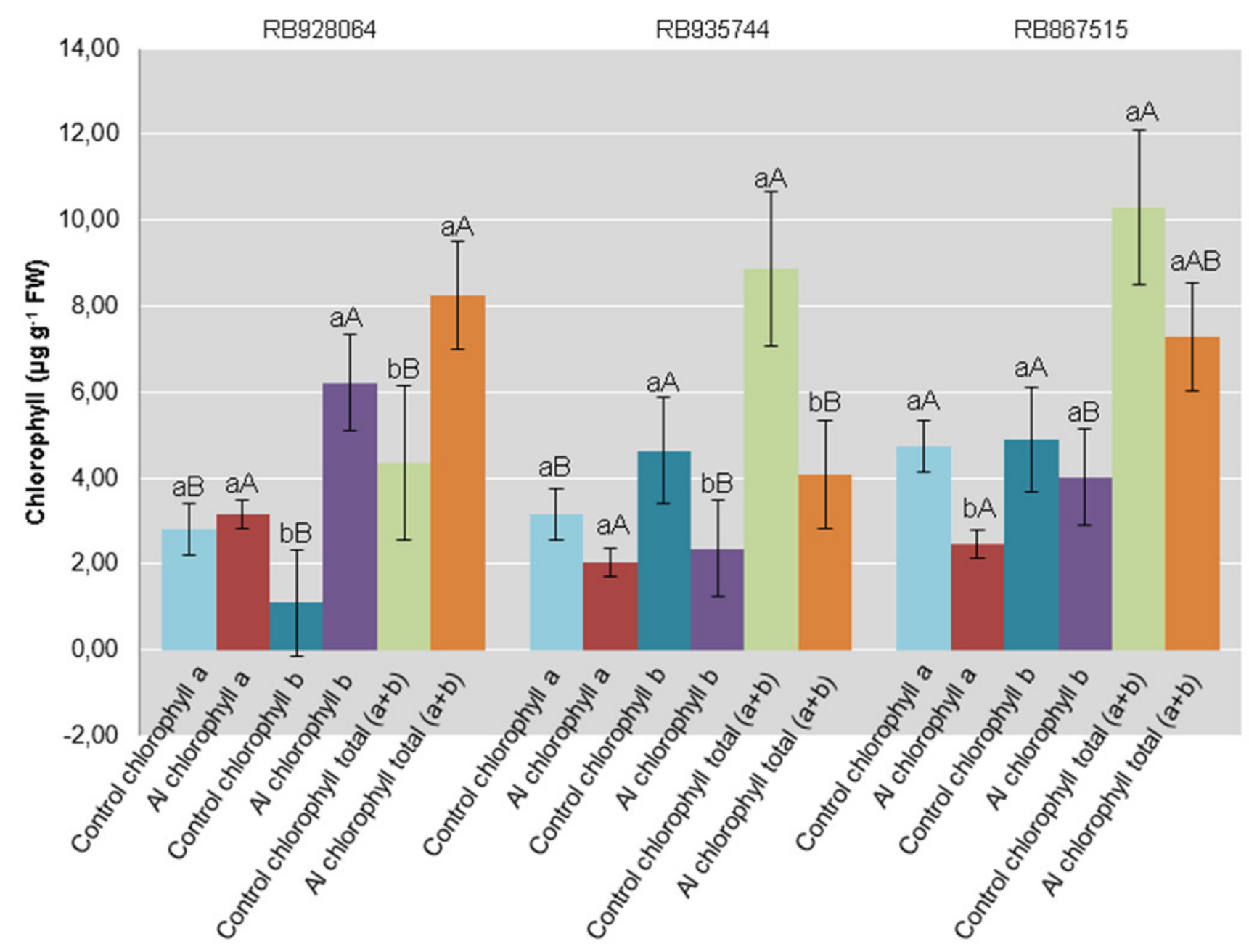




\section{Figure 5}

Expression of genes of sugarcane cultivars in nutrient solution at different levels of $\mathrm{Al}$ stress $\left(0\right.$ and $\left.3000 \mu \mathrm{mol} \mathrm{L}^{-1}\right)$

Expression of genes related to Al tolerance in plants submitted to Al-treatment in comparison with the control plants. Polyubiquitin gene was used as a reference gene. Bars represents the average of relative expression of $S D H, M D H$ and $S O D$ of each cultivar (the average was composed of the appropriate biological duplicates and triplicates of the GPCR reaction). The error bars were calculated according to Livak and Schmittgen (2001). Asterisks indicate significant values (t test, $p<0.05 ; 95 \%$ prediction interval). 

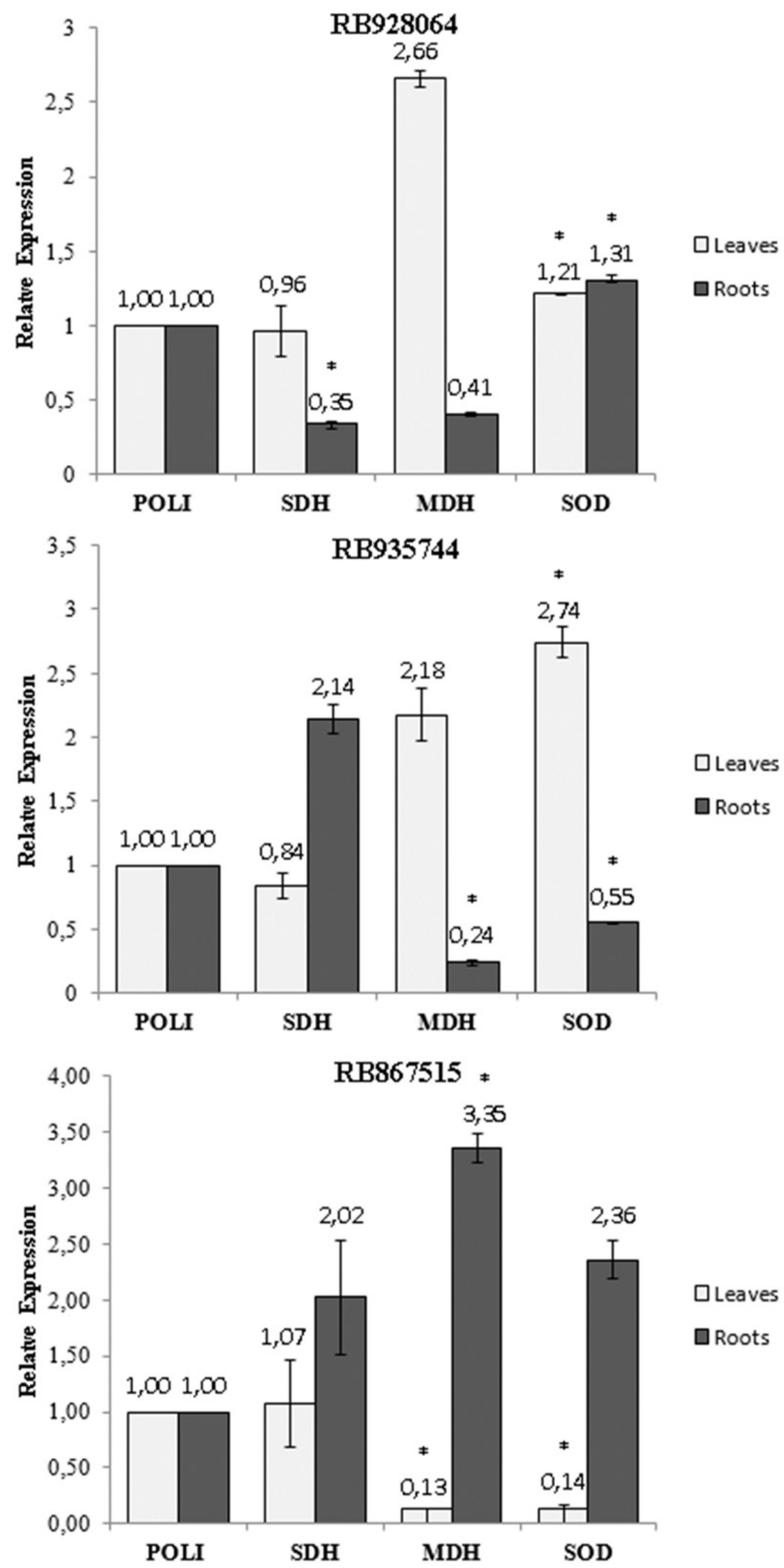